\title{
Annual Report on the External Quality Assessment Scheme for Diagnostic Genetics in Korea (2014)
}

\author{
Chang-Hun Park ${ }^{1}$, \\ Sang-Yong Shin ${ }^{1}$, \\ Hyunwoong Park ${ }^{2}$, \\ Sung Im $\mathrm{Cho}^{2}$, \\ Moon-Woo Seong ${ }^{2}$, \\ Sung Sup Park ${ }^{2}$, and \\ Sun-Hee Kim ${ }^{1}$, as \\ Diagnostic Genetics \\ Subcommittee, The \\ Korean Association \\ of External Quality \\ Assessment Service \\ ${ }^{1}$ Department of Laboratory \\ Medicine and Genetics, \\ Samsung Medical Center, \\ Sungkyunkwan University \\ School of Medicine; \\ ${ }^{2}$ Department of Laboratory \\ Medicine, Seoul National \\ University Hospital, Seoul, \\ Korea
}

Corresponding author: Sun-Hee Kim

Department of Laboratory Medicine and Genetics, Samsung Medical Center, Sungkyunkwan University School of Medicine, 81 Irwon-ro, Gangnam-gu, Seoul 135-710, Korea

Tel: $+82-2-3410-2704$

Fax: +82-2-3410-2719

E-mail: sunnyhk@skku.edu
Quality control for genetic tests has become more important as testing volume and clinical demands have increased dramatically. The diagnostic genetics subcommittee of Korean Association of External Quality Assessment Service conducted two trials in 2014 based on cytogenetics and molecular genetics surveys. A total of 44 laboratories participated in the chromosome surveys, 33 laboratories participated in the fluorescence in situ hybridization (FISH) surveys, and 130 laboratories participated in the molecular genetics surveys as a part of these trials. All laboratories showed acceptable results in the chromosome and FISH surveys. The molecular genetics surveys included various tests: Mycobacterium tuberculosis detection, hepatitis $\mathrm{B}$ and $\mathrm{C}$ virus detection and quantification, human papilloma virus genotyping, gene rearrangement tests for leukaemia and lymphomas, genetic tests for JAK2, FMS-like tyrosine kinase 3, nucleophosmin, cancer-associated genes (KRAS, EGFR, KIT, and $B R A F)$, hereditary breast and ovarian cancer genes (BRCA1 and BRCA2), Li-Fraumeni syndrome (TP53), Wilson disease (ATP7B), achondroplasia (FGFR3), Huntington disease, spinocerebellar ataxia, spinal and bulbar muscular atrophy, mitochondrial encephalopathy with lactic acidosis and stroke like episodes, myoclonic epilepsy ragged red fibre, PraderWilli/Angelman syndrome, Duchenne muscular dystrophy, spinal muscular atrophy, fragile $\mathrm{X}$ syndrome, nonsyndromic hearing loss and deafness (GJB2), multiple endocrine neoplasia 2 (RET), Leber hereditary optic neuropathy (major mutation), apolipoprotein E genotyping, methylenetetrahydrofolate reductase genotyping, $\mathrm{ABO}$ genotyping, and DNA sequencing analysis. Molecular genetic surveys showed excellent results for most of the participants. The external quality assessment program for genetic analysis in 2014 proved to be helpful for continuous education and the evaluation of quality improvement.

\section{(J Lab Med Qual Assur 2015;37:64-83)}

Key Words: Healthcare quality assurance, Molecular diagnostic testing, Gytogenetics, Moleculur bidogy

\section{서론}

2014년에도 예년과 마찬가지로 2회의 염색체검사 분야 의 정도관리사업을 실시하였다. 총 9예의 핵형사진을 분석 (karyotyping)하고 1예의 말초혈액은 각 기관에서 직접 배양
한 후 분석하는 방법으로 신빙도검사를 실시하였다. 2009년부 터 fluorescence in situ hybridization (FISH)검사를 정도관 리사업으로 실시하였으며[1], 2013년부터 염색체검사와 마찬 가지로 2회의 FISH검사를 실시하였다. 총 10예의 FISH검사 용 슬라이드를 발송하였고 검사실에서 직접 검사를 실시한 후 


\title{
Journal of LABORATORY MEDICINE and QUALITY ASSURANCE
}

\author{
Chang-Hun Park et al • 2014 Report on the External Quality Assessment
}

판독결과를 보고하도록 하였다. 합격/불합격의 기준은 결과 를 제출한 interpretation에 기초하였을 때, 참여한 모든 예의 $60 \%$ 이상의 검사결과에서 acceptable performance를 보인 경우를 최종합격으로 판정하였다[1-4].

2014년도 분자미생물검사 정도관리는 6종의 검사를 대상 으로 전체 회원기관에서 참가 신청 조사를 하여 총 2 회 시행 하였고 분자유전검사 정도관리는 1 차와 2 차의 31 종의 검사를 대상으로, multiple endocrine neoplasia 2 (RET)와 Leber hereditary optic neuropathy (major mutation)의 2종의 항 목을 신설하였다. 또한 $B R C A 1$ 과 $B R C A 2$ 분자유전검사를 구 분하였고 DNA 염기서열분석항목에는 새로운 유전자와 다양 한 종류의 돌연변이를 포함하였다. 합격/불합격의 기준은 10 기관 미만의 참여항목의 경우 주관기관의 예상결과와 일치하 는 경우 acceptable이라고 판정하였으며 10기관 이상의 참여 항목의 경우 주관기관의 예상결과와 참여기관 중 $70 \%$ 이상 의 일치가 있을 경우 acceptable이라고 판정하였다. 삼염기 반 복질환(Huntington disease [HD], spinocerebellar ataxia [SCA], spinal and bulbar muscular atrophy [SBMA], fragile X syndrome [FMR1])이나 hepatitis B virus (HBV) 나 hepatitis $\mathrm{C}$ virus (HCV) 정량검사의 정량값은 평가에는 포함시키지 않고 통계만 제시하였다.

\section{재료 및 방법}

\section{1. 세포유전검사}

2014 년도에는 2 회에 걸쳐 각각 4 예와 5 예의 정도관리용 사 진 그리고 1 예의 말초혈액 검체를 발송하여 염색체검사의 핵 형분석에 대한 정도관리를 실시하였다. 2014년 5월에 실시된 첫 번째 염색체검사 정도관리 프로그램에서는 총 4예(14CY$01,14 \mathrm{CY}-02,14 \mathrm{CY}-03,14 \mathrm{CY}-04)$ 에 대하여 환자의 간단 한 임상정보를 발송하고 대한임상검사정도관리협회 홈페이 지(http://www.lab-qa.org) 또는 한국유전자검사평가원 홈 페이지(http://www.kigte.org)에서 세포분열중기 사진을 다 운로드받아 분석하도록 하였으며 1예(14CY-05)에 대하여 말 초혈액 검체를 발송하였다. 2014년 9월에 실시된 두 번째 염 색체검사 정도관리 프로그램은 총 5예(14CY-06 14CY-07, $14 \mathrm{CY}-08,14 \mathrm{CY}-09,14 \mathrm{CY}-10)$ 에 대하여 마찬가지로 임상정 보를 발송하였으며 분열중기 사진을 다운로드받아 분석하도 록 하였다.

검사결과의 보고는 각 검사실에서 사용하는 통상적 방법 으로 분열중기세포를 분석한 후 최종 핵형 결과를 인체 염색 체 명명법의 국제규약 즉, International System of Human
Cytogenetic Nomenclature (ISCN) 2013의 단축형에 따라 기술하도록 하였다[5]. 결과 분석방법으로는 각 검체에 대 한 핵형을 modal chromosome number (M), sex chromosome designation $(\mathrm{S})$, recognition of abnormalities (A), karyotype nomenclature $(\mathrm{N})$ 와 같은 $\mathrm{M}, \mathrm{S}, \mathrm{A}, \mathrm{N}$ 의 네 가지 요소로서 평가하였다. 각 네 가지 요소에 대한 평가등급은 $\square$, [1, 2], 3으로 분류하였으며, 각각 $\square$ : not graded, 1]: good performance, 2]: acceptable performance, 3]: unacceptable performance를 나타낸다. 2002년도부터는 지난 5년간 성적을 바탕으로 4 곳의 참고기관을 선정하여 이들의 결과를 참고하였고, 각 검체에 대한 핵형의 target value는 '참고기 관의 $75 \%$ 이상 및 참여기관 다수의 의견일치가 있는 경우로 정의하였다. 적절한 절단점으로 인정하는 기준은 "two-band rule'을 따랐는데 이는 최빈수의 절단점으로부터 two-band 또 는 two-subband 내에 있는 절단점만을 인정하는 것이다. 각 기관에서 회신한 핵형의 명명이 ISCN 2013의 원칙에 벗어난 경우 결과요약지의 의견란(comments)에 구체적으로 평가의 견을 기술하였다.

$\mathrm{FISH}$ 검사에 대한 정도관리사업은 2회에 걸쳐 각각 5 예 의 FISH검사용 슬라이드를 발송하였다. 2014년 5월에 실시 된 첫 번째 FISH 검사항목은 총 5예(14CYF-01, $14 \mathrm{CYF}-02$, 14CYF-03, 14CYF-04, 14CYF-05)로 Trisomy 21, PraderWilli/Angelman syndrome, BCR/ABL1, CDKN2A on chromosome 9, D7S522 on chromosome 7항목에 대해서 실 시하였다. 2014년 9월에 실시된 두 번째 FISH검사항목은 총 5예(14CYF-08, 14CYF-09, 14CYF-10, 14CYF-11, 14CYF12)로 Trisomy 21, X/Y, PML/RARa, D13S319 on 13q14, TP53 on 17p31항목에 대해서 실시하였다. 발송된 FISH 슬 라이드는 각 항목별로 이상이 관찰된 검체로 슬라이드를 제작 한 것으로 참가기관별로 정도관리사업에 참여하는 항목에 대 해서 슬라이드를 2장씩 보냈다. 각 참가기관에서는 받은 슬라 이드에 각 검사실에서 사용하는 통상적 방법으로 검사를 시 행한 후 ISCN 2013에 따른 명명법과 함께 signal pattern에 대한 판독결과를 보고하도록 하였다[5]. 합격, 불합격 여부는 signal pattern에 대한 판독결과만을 기준으로 판단하였다.

\section{2. 분자유전검사}

1 차 조사는 미생물 및 인체 유전자검사의 경우 4 월 28 일에 검체를 발송하고 9 월 2 일에 결과를 게시하였다. 2 차 조사는 9 월 3 일에 검체를 발송하였고, 12 월 10 일에 결과를 게시하였 다. 정도관리물질 제조와 준비는 Table 1 과 같이 시행하였다. 각 기관의 보고에 따라 검사방법, 검사결과 및 검사방법별 검 


\section{Journal of LABORATORY MEDICINE and QUALITY ASSURANCE}

Chang-Hun Park et al • 2014 Report on the External Quality Assessment

Table 1. Survey tests and specimens for external quality assessment of the molecular genetics test survey in 2014

\begin{tabular}{|c|c|c|c|c|}
\hline Tests & Specimens & Test specimens of 1 st trial & Specimens & Test specimens of $2 \mathrm{nd}$ trial \\
\hline \multirow[t]{2}{*}{ HPV } & MD 1401-A & HPV positive cell line & MD 1402-A & Human normal control cell line \\
\hline & MD 1401-B & Human normal control cell line & MD 1402-B & HPV positive cell line \\
\hline \multirow[t]{2}{*}{ M. tuberculosis } & MD 1401-C & M. tuberculosis & MD 1402-C & NTM \\
\hline & MD 1401-D & NTM & MD 1402-D & M. tuberculosis \\
\hline \multirow[t]{3}{*}{ HBV detection } & MD 1401-E & HBV high positive plasma & MD 1402-E & HBV high positive plasma \\
\hline & MD 1401-F & HBV low positive plasma & MD 1402-F & HBV low positive plasma \\
\hline & MD 1401-G & Normal pooled plasma & MD 1402-G & Normal pooled plasma \\
\hline \multirow[t]{3}{*}{ HBV quantification } & MD 1401-H & HBV high positive plasma & MD 1402-H & HBV high positive plasma \\
\hline & MD 1401-I & Normal pooled plasma & MD 1402-I & HBV low positive plasma \\
\hline & MD 1401-J & HBV low positive plasma & MD 1402-J & Normal pooled plasma \\
\hline \multirow[t]{3}{*}{ HCV detection } & MD 1401-K & HCV low positive plasma & MD 1402-K & Normal pooled plasma \\
\hline & MD 1401-L & HCV high positive plasma & MD 1402-L & HCV high positive plasma \\
\hline & MD 1401-M & Normal pooled plasma & MD 1402-M & HCV low positive plasma \\
\hline \multirow[t]{3}{*}{ HCV quantification } & MD 1401-N & Normal pooled plasma & MD $1402-\mathrm{N}$ & Normal pooled plasma \\
\hline & MD 1401-O & HCV high positive plasma & MD 1402-O & HCV high positive plasma \\
\hline & MD 1401-P & HCV low positive plasma & MD 1402-P & HCV low positive plasma \\
\hline \multirow[t]{2}{*}{ Leukaemia/Lymphoma } & MD 1401-01 & Leukaemia cell line ( $B C R / A B L 1$ positive) & MD 1402-01 & Leukaemia cell line ( $P M L / R A R A$ positive) \\
\hline & MD 1401-02 & Leukaemia cell line ( $P M L / R A R A$ positive) & MD 1402-02 & Leukaemia cell line (TEL/AML1 positive) \\
\hline \multirow[t]{2}{*}{$J A K 2$} & MD 1401-03 & Cell line with $J A K 2$ mutation & MD 1402-03 & Cell line with $J A K 2$ mutation \\
\hline & MD 1401-04 & Normal cell line & MD 1402-04 & Normal cell line \\
\hline \multirow[t]{2}{*}{ FLT3 -ITD } & MD 1401-05 & Extracted DNA with FLT3-ITD mutation & MD 1402-05 & Normal DNA \\
\hline & MD 1401-06 & Normal DNA & MD 1402-06 & Extracted DNA with FLT3-ITD mutation \\
\hline \multirow[t]{2}{*}{ FLT3-TKD } & MD 1401-07 & Extracted DNA with FLT3-TKD mutation & MD 1402-07 & Extracted DNA with FLT3-KTD mutation \\
\hline & MD 1401-08 & Normal DNA & MD 1402-08 & Normal DNA \\
\hline \multirow[t]{2}{*}{ NPM1 } & MD 1401-09 & Extracted DNA with NPM1 mutation & MD 1402-09 & Extracted DNA with $N P M 1$ mutation \\
\hline & MD 1401-10 & Normal DNA & MD 1402-10 & Normal DNA \\
\hline \multirow[t]{2}{*}{ KRAS } & MD 1401-11 & Cell line with $K R A S$ mutation & MD 1402-11 & Cell line with $K R A S$ mutation \\
\hline & MD 1401-12 & Normal cell line & MD 1402-12 & Normal cell line \\
\hline \multirow[t]{2}{*}{$B R A F$} & MD 1401-13 & Cell line with $B R A F$ mutation & MD 1402-13 & Cell line with $B R A F$ mutation \\
\hline & MD 1401-14 & Normal cell line & MD 1402-14 & Normal cell line \\
\hline \multirow[t]{2}{*}{ EGFR } & MD 1401-15 & Normal cell line & MD 1402-15 & Cell line with EGFR mutation \\
\hline & MD 1401-16 & Cell line with EGFR mutation & MD 1402-16 & Normal cell line \\
\hline \multirow[t]{2}{*}{ KIT } & MD 1401-17 & Normal cell line & MD 1402-17 & Normal cell line \\
\hline & MD 1401-18 & Cell line with KIT mutation & MD 1402-18 & Cell line with KIT mutation \\
\hline \multirow[t]{2}{*}{$B R C A 1$} & MD 1401-19 & Cell line with $B R C A 1$ mutation & MD 1402-19 & Cell line with $B R C A 1$ mutation \\
\hline & MD 1401-20 & Normal cell line & MD 1402-20 & Normal cell line \\
\hline \multirow[t]{2}{*}{$B R C A 2$} & MD 1401-19 & Normal cell line & MD 1402-19 & Normal cell line \\
\hline & MD 1401-20 & Cell line with $B R C A 2$ mutation & MD 1402-20 & Cell line with $B R C A 2$ mutation \\
\hline \multirow[t]{2}{*}{ TP53 } & MD 1401-21 & Cell line with TP53 mutation & MD 1402-21 & Normal cell line \\
\hline & MD 1401-22 & Normal cell line & MD 1402-22 & Cell line with TP53 mutation \\
\hline
\end{tabular}

(Continued to the next page) 


\section{Journal of LABORATORY MEDICINE and QUALITY ASSURANCE}

Chang-Hun Park et al • 2014 Report on the External Quality Assessment

Table 1. Continued

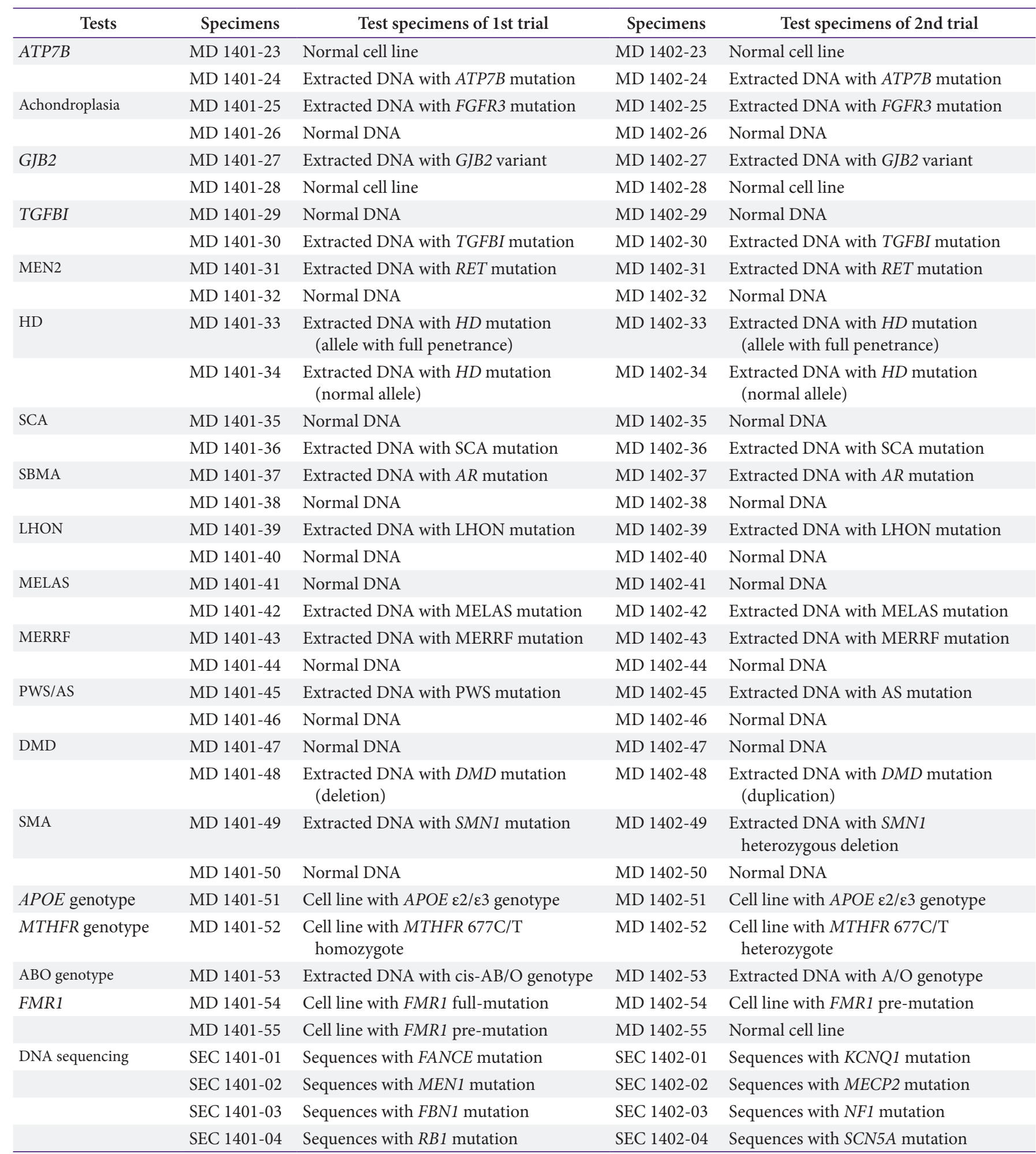

Abbreviations: HPV, human papilloma virus; HBV, hepatitis B virus; HCV, hepatitis C virus; NTM, nontuberculosis mycobacteria; MEN2, multiple endocrine neoplasia 2; HD, Huntington disease; SCA, spinocerebellar ataxia; SBMA, spinal and bulbar muscular atrophy; LHON, Leber hereditary optic neuropathy; MELAS, mitochondrial encephalomyopathy, lactic acidosis, and stroke-like episodes; MERRF, myoclonic epilepsy with ragged red fibres; PWS/AS, Prader-Willi/Angelman syndrome; DMD, Duchenne muscular dystrophy; SMA, spinal muscular atrophy; M. tuberculosis, Mycobacterium tuberculosis; FLT3, FMS-like tyrosine kinase 3 gene; NPM1, Nucleophosmin 1 gene. 


\section{Journal of LABORATORY MEDICINE and QUALITY ASSURANCE}

Chang-Hun Park et al • 2014 Report on the External Quality Assessment

사결과를 비교 분석하였다. 또한 기관별 보고결과에 대하여 기본적인 평가(acceptable, unacceptable)를 실시하였다. 삼 염기 질환 $(\mathrm{HD}, \mathrm{SCA}, \mathrm{SBMA}, \mathrm{FMR} 1)$ 의 반복 수와 $\mathrm{HBV}$ 와 $\mathrm{HCV}$ 정량검사의 기관별 검사결과를 참고로 제시하였다.

\section{결과}

\section{1. 세포유전검사}

2014년 5월에 실시된 제1차 염색체검사 정도관리사업에서
는 총 44개 기관에 발송하여 44개 기관으로부터 결과회신을 받았다. 9월에 실시된 제 2 차 염색체검사 정도관리에서는 1 개 기관에서 상반기 1 회만 참여하여 총 43 개 기관에 발송하여 43 개 기관으로부터 결과회신을 받았다. 검체별 결과분석 내용은 Table 2 와 같다. 제 1,2 차 염색체검사 정도관리의 결과를 제시 된 합격/불합격의 기준에 따라 판정하였을 때 참여한 기관 중 총 43 개 기관이 합격 판정을 받았다.

2014년 5월에 실시된 제1차 FISH검사 정도관리사업에는 총 32 개 기관에 발송하여 32 개 기관으로부터 결과회신을 받았

Table 2. Results of the cytogenetics survey in 2014

\begin{tabular}{|c|c|c|c|c|c|c|c|}
\hline \multirow{2}{*}{ Specimen } & \multirow{2}{*}{ Karyotype } & \multicolumn{4}{|c|}{ Grading } & \multirow{2}{*}{ Referee } & \multirow{2}{*}{ Participants } \\
\hline & & M & $S$ & A & $\mathrm{N}$ & & \\
\hline \multirow[t]{5}{*}{ 14CY-01 } & $46, \mathrm{XX}, \operatorname{del}(22)(\mathrm{q} 13.2)$ & 1 & 1 & (1] & 1 & $4(100)$ & $15(37.5)$ \\
\hline & 46,XX,del(22)(q13.3) & 1 & [1] & $1]$ & 10 & 0 & $13(32.5)$ \\
\hline & 46,XX,del(22)(q13.1) & 1 & 1 & 1 & 1 & 0 & $8(20.0)$ \\
\hline & $46, \mathrm{XX}, \operatorname{del}(22)(\mathrm{q} 12.2 \mathrm{q} 13.1)$ & $1]$ & 10 & 2 & 2 & 0 & $2(5.0)$ \\
\hline & $46, \mathrm{XX}, \operatorname{del}(22)(\mathrm{q} 13.1 \mathrm{q} 13.3)$ & $1]$ & 1 & 2 & $2]$ & 0 & $2(5.0)$ \\
\hline \multirow[t]{9}{*}{$14 \mathrm{CY}-02$} & $46, \mathrm{X}, \operatorname{del}(\mathrm{X})(\mathrm{p} 22.1)$ & 11 & 10 & 10 & 10 & $2(50)$ & $23(57.5)$ \\
\hline & 46,X,del(X)(p22.2) & $1]$ & {$[1]$} & $1]$ & $1]$ & $2(50)$ & $7(17.5)$ \\
\hline & $46, \mathrm{X}, \operatorname{del}(\mathrm{X})(\mathrm{p} 22.31)$ & 1 & 1 & 1 & 1 & 0 & $3(7.5)$ \\
\hline & 46,X,del(X)(p22.13) & 11 & 10 & 11 & 10 & 0 & $1(2.5)$ \\
\hline & 46,X,del(X)(p22.1),22ps+ & $1]$ & {$[1]$} & $1]$ & $2]$ & 0 & $1(2.5)$ \\
\hline & 46,XX,del $(\mathrm{X})(\mathrm{p} 22.1)$ & 1 & 1 & 1 & 3 & 0 & $2(5.0)$ \\
\hline & $46, \mathrm{X}, \mathrm{del}(\mathrm{X})(\mathrm{q} 22.1)$ & $1]$ & 10 & 3 & 3 & 0 & $1(2.5)$ \\
\hline & $46, \mathrm{X}, \mathrm{t}(\mathrm{X} ; 22)(\mathrm{p} 22.1 ; \mathrm{p} 11.2)$ & 1 & {$[1]$} & 3 & 3 & 0 & $1(2.5)$ \\
\hline & 46,XX,t(X;22)(p21.1;p13) & 1 & 1 & 3 & 3 & 0 & $1(2.5)$ \\
\hline \multirow[t]{6}{*}{$14 \mathrm{CY}-03$} & $46, \mathrm{XY}, \operatorname{del}(5)(\mathrm{q} 15 \mathrm{q} 31), \mathrm{t}(9 ; 22)(\mathrm{q} 34 ; \mathrm{q} 11.2)[\mathrm{n}]$ & $1]$ & 11 & 11 & 1 & $4(100)$ & $33(82.5)$ \\
\hline & 46,XY,del(5)(q22q31),t(9;22)(q34;q11.2)[n] & 1 & 10 & 10 & $1]$ & 0 & $2(5.0)$ \\
\hline & 46,XY,del(5)(q13q22),t(9;22)(q34;q11.2)[n] & 1 & 11 & 1 & $1]$ & 0 & $2(5.0)$ \\
\hline & 46,XY,del(5)(q22q31.3),t(9;22)(q34;q11.2)[n] & $1]$ & $1]$ & 1 & 2 & 0 & $1(2.5)$ \\
\hline & $46, \mathrm{XY}, \operatorname{del}(5)(\mathrm{q} 15 \mathrm{q} 31), \operatorname{der}(9) \mathrm{t}(9 ; 22)(\mathrm{q} 34 ; \mathrm{q} 11.2)[\mathrm{n}]$ & {$[1]$} & 10 & 3 & 3 & 0 & $1(2.5)$ \\
\hline & $46, \mathrm{XY}, \operatorname{del}(5)(\mathrm{q} 15 \mathrm{q} 31), \mathrm{t}(9 ; 22)(\mathrm{q} 34 ; 11.2)[\mathrm{n}]$ & 1 & 10 & 3 & 3 & 0 & $1(2.5)$ \\
\hline \multirow[t]{9}{*}{$14 \mathrm{CY}-04$} & $47, \mathrm{XY}, \mathrm{t}(6 ; 14)(\mathrm{p} 21.1 ; \mathrm{q} 32),+12[\mathrm{n}]$ & $1]$ & $1]$ & $1]$ & [1] & $3(75)$ & $23(57.5)$ \\
\hline & $47, \mathrm{XY}, \mathrm{t}(6 ; 14)(\mathrm{p} 21.1 ; \mathrm{q} 32.3),+12[\mathrm{n}]$ & $1]$ & $1]$ & {$[1]$} & [1] & 0 & $7(17.5)$ \\
\hline & $47, \mathrm{XY}, \mathrm{t}(6 ; 14)(\mathrm{p} 21.1 ; \mathrm{q} 32.1),+12[\mathrm{n}]$ & 1 & 1 & 1 & $1]$ & 0 & $3(7.5)$ \\
\hline & $47, \mathrm{XY}, \mathrm{t}(6 ; 14)(\mathrm{p} 21.2 ; \mathrm{q} 32),+12[\mathrm{n}]$ & 10 & 10 & 11 & 10 & 0 & $3(7.5)$ \\
\hline & $47, \mathrm{XY}, \mathrm{t}(6 ; 14)(\mathrm{p} 21.3 ; \mathrm{q} 32.3),+12[\mathrm{n}]$ & $1]$ & $1]$ & $1]$ & 1 & 0 & $1(2.5)$ \\
\hline & $47, \mathrm{XY}, \mathrm{t}(6 ; 14)(\mathrm{p} 12 ; \mathrm{q} 32),+12[\mathrm{n}]$ & {$[1]$} & 11 & {$[1]$} & {$[1]$} & $1(25)$ & 0 \\
\hline & $47, \mathrm{XY}, \mathrm{t}(6 ; 14)(\mathrm{p} 21.2 ; \mathrm{q} 32.3),+12[\mathrm{n}]$ & [1] & 11 & [1] & $1]$ & 0 & $1(2.5)$ \\
\hline & $47, \mathrm{XY}, \mathrm{t}(6 ; 14)(\mathrm{p} 21.3 ; \mathrm{q} 32),+12[\mathrm{n}]$ & 11 & 1 & 11 & 11 & 0 & $1(2.5)$ \\
\hline & $47, \mathrm{XY}, \mathrm{t}(6 ; 14)(\mathrm{p} 21 ; \mathrm{q} 32),+12[\mathrm{n}]$ & [1] & {$[1]$} & {$[1]$} & 2 & 0 & $1(2.5)$ \\
\hline
\end{tabular}


Journal of LABORATORY MEDICINE and QUALITY ASSURANCE

Chang-Hun Park et al • 2014 Report on the External Quality Assessment

Table 2. Contineud

\begin{tabular}{|c|c|c|c|c|c|c|c|}
\hline \multirow{2}{*}{ Specimen } & \multirow{2}{*}{ Karyotype } & \multicolumn{4}{|c|}{ Grading } & \multirow{2}{*}{ Referee } & \multirow{2}{*}{ Participants } \\
\hline & & $M$ & $S$ & $\mathrm{~A}$ & $\mathrm{~N}$ & & \\
\hline \multirow[t]{8}{*}{ 14CY-05 } & $46, \mathrm{XY}, \operatorname{inv}(1)(\mathrm{q} 25.3 \mathrm{q} 42.1)$ & 1 & 1 & [1] & 1 & $4(100)$ & $30(75.0)$ \\
\hline & 46,XY,inv(1)(q25.1q42.1) & 1 & 11 & [1] & 11 & 0 & $2(5.0)$ \\
\hline & $46, \mathrm{XY}, \operatorname{inv}(1)(\mathrm{q} 31 \mathrm{q} 41)$ & $1]$ & $1]$ & $1]$ & $1]$ & 0 & $2(5.0)$ \\
\hline & $46, \mathrm{XY}, \operatorname{inv}(1)(\mathrm{q} 25.3 \mathrm{q} 42.11)$ & 1 & (1] & $1]$ & 1 & 0 & $2(5.0)$ \\
\hline & $46, X Y, \operatorname{inv}(1)(q 31.2 q 32.3)$ & 1 & 1 & 1 & 1 & 0 & $1(2.5)$ \\
\hline & $46, \mathrm{XY}, \operatorname{inv}(1)(\mathrm{q} 25.2 \mathrm{q} 42.1)$ & 1 & [1] & (1] & 1 & 0 & $1(2.5)$ \\
\hline & $46, \mathrm{XY}, \operatorname{inv}(1)(\mathrm{q} 25 \mathrm{q} 42)$ & $1]$ & [1] & {$[1]$} & [2] & 0 & $1(2.5)$ \\
\hline & 46,XY,inv(1)(q25.3q42) & 1 & 1 & $1]$ & 2 & 0 & $1(2.5)$ \\
\hline \multirow[t]{3}{*}{$14 \mathrm{CY}-06$} & $46, \mathrm{XX}, \mathrm{t}(2 ; 19)(\mathrm{q} 33 ; \mathrm{p} 13.1)$ & 1 & [1] & $1]$ & 1 & $4(100)$ & $37(94.9)$ \\
\hline & $46, \mathrm{XX}, \mathrm{t}(2 ; 9)(\mathrm{q} 33 ; \mathrm{p} 13.1)$ & 1] & (1] & 3 & 3 & 0 & $1(2.6)$ \\
\hline & 46,XY,t(2;19)(q33;p13.1) & 10 & 3 & [1] & 3 & 0 & $1(2.6)$ \\
\hline \multirow[t]{12}{*}{$14 \mathrm{CY}-07$} & $47, \mathrm{XY}, \mathrm{t}(3 ; 21)(\mathrm{p} 13 ; \mathrm{q} 22.1),+21$ & 1 & 1 & {$[1]$} & 1 & $2(50)$ & $26(65.0)$ \\
\hline & $47, \mathrm{XY}, \mathrm{t}(3 ; 21)(\mathrm{p} 11.2 ; \mathrm{q} 11.2),+21$ & 1 & 1 & $1]$ & [1] & $1(25)$ & 0 \\
\hline & $47, \mathrm{XY}, \mathrm{t}(3 ; 21)(\mathrm{p} 12 ; \mathrm{q} 21),+21$ & 1 & 1 & [1] & 1 & $1(25)$ & 0 \\
\hline & $47, \mathrm{XY}, \mathrm{t}(3 ; 21)(\mathrm{p} 14,2 ; \mathrm{q} 22.1),+21$ & 1 & 11 & [1] & 1 & 0 & $1(2.5)$ \\
\hline & $47, \mathrm{XY}, \mathrm{t}(3 ; 21)(\mathrm{p} 14.2 ; \mathrm{q} 22.1),+21$ & 1 & 1 & [1] & [1] & 0 & $4(10.0)$ \\
\hline & $47, \mathrm{XY}, \mathrm{t}(3 ; 21)(\mathrm{p} 21.1 ; \mathrm{q} 22.2),+21$ & 1 & 11 & [1] & 1 & 0 & $1(2.5)$ \\
\hline & $47, \mathrm{XY}, \mathrm{t}(3 ; 21)(\mathrm{p} 21.1 ; \mathrm{q} 22.3),+21$ & 1 & {$[1]$} & {$[1]$} & 1 & 0 & $1(2.5)$ \\
\hline & $47, \mathrm{XY}, \mathrm{t}(3 ; 21)(\mathrm{p} 21.3 ; \mathrm{q} 22.3),+21$ & 1 & [1] & 10 & 1 & 0 & $1(2.5)$ \\
\hline & $47, \mathrm{XY}, \mathrm{t}(3 ; 21)(\mathrm{p} 10 ; \mathrm{p} 10),+21$ & 1 & [1] & 10 & 3 & 0 & $2(5.0)$ \\
\hline & $47, \mathrm{XY}, \mathrm{t}(3 ; 21)(\mathrm{p} 14.2 ; \mathrm{q} 22.1)$ & 1 & [1] & 3 & 3 & 0 & $1(2.5)$ \\
\hline & $47, \mathrm{XY}, \operatorname{del}(3)(\mathrm{p} 21.1),+\operatorname{del}(3)(\mathrm{q} 10)$ & 1 & [1] & 3 & 3 & 0 & $1(2.5)$ \\
\hline & $46, \mathrm{XY}, \mathrm{t}(3 ; 21)(\mathrm{q} 11.2 ; \mathrm{p} 11.2),+21$ & 3 & {$[1]$} & $1]$ & 3 & 0 & $1(2.5)$ \\
\hline \multirow[t]{11}{*}{$14 \mathrm{CY}-08$} & $46, \mathrm{XY}, \operatorname{del}(3)(\mathrm{q} 23 \mathrm{q} 25.3)$ & 1 & $1]$ & 1 & 11 & $4(100)$ & $14(35.0)$ \\
\hline & 46,XY,del(3)(q21q23) & 10 & {$[1]$} & 10 & 1 & 0 & $13(32.5)$ \\
\hline & 46,XY,del(3)(q22q24) & [1] & [1] & [1] & 1 & 0 & $2(5.0)$ \\
\hline & 46,XY,del(3)(q22q25.1) & 10 & 10 & 1 & 11 & 0 & $2(5.0)$ \\
\hline & 46,XY,del(3)(q23q25.1) & 1 & $1]$ & (1) & 1 & 0 & $2(5.0)$ \\
\hline & 46,XY,del(3)(q21q23) & [1] & {$[1]$} & (1) & 1 & 0 & $1(2.5)$ \\
\hline & 46,XY,del(3)(q21q24) & 1 & [1] & 11 & 1 & 0 & $1(2.5)$ \\
\hline & 46,XY,del(3)(q21q25.1) & 1 & {$[1]$} & [1] & 1 & 0 & $1(2.5)$ \\
\hline & 46,XY,del(3)(q22q23) & 10 & {$[1]$} & (1) & 1 & 0 & $1(2.5)$ \\
\hline & 46,XY,del(3)(q22q25.3) & $1]$ & {$[1]$} & [1] & $1]$ & 0 & $1(2.5)$ \\
\hline & $46, \mathrm{XY}, \mathrm{del}(3)(\mathrm{q} 23 \mathrm{q} 25)$ & {$[1]$} & {$[1]$} & [1] & $2]$ & 0 & $1(2.5)$ \\
\hline \multirow[t]{5}{*}{ 14CY-09 } & $46, \mathrm{XY}, \mathrm{t}(8 ; 9 ; 21)(\mathrm{q} 22 ; \mathrm{q} 34 ; \mathrm{q} 22), \operatorname{del}(9)(\mathrm{q} 13 \mathrm{q} 22)[\mathrm{n}]$ & 10 & [1] & [1] & {$[1]$} & 0 & $7(17.5)$ \\
\hline & $46, \mathrm{XY}, \mathrm{t}(8 ; 9 ; 21)(\mathrm{q} 22 ; \mathrm{q} 32 ; \mathrm{q} 22), \operatorname{del}(9)(\mathrm{q} 22 \mathrm{q} 32)[\mathrm{n}]$ & 11 & [1] & (1) & 11 & $2(50)$ & $3(7.5)$ \\
\hline & $46, \mathrm{XY}, \mathrm{t}(8 ; 9 ; 21)(\mathrm{q} 22 ; \mathrm{q} 32 ; \mathrm{q} 22), \operatorname{del}(9)(\mathrm{q} 13 \mathrm{q} 22)[\mathrm{n}]$ & [1] & {$[1]$} & {$[1]$} & 1 & 0 & $4(10.0)$ \\
\hline & $46, \mathrm{XY}, \mathrm{t}(8 ; 9 ; 21)(\mathrm{q} 22 ; \mathrm{q} 32 ; \mathrm{q} 22), \operatorname{del}(9)(\mathrm{q} 22 \mathrm{q} 34)[\mathrm{n}]$ & $1]$ & [1] & {$[1]$} & {$[1]$} & 0 & $4(10.0)$ \\
\hline & $46, \mathrm{XY}, \mathrm{t}(8 ; 9 ; 21)(\mathrm{q} 22 ; \mathrm{q} 33 ; \mathrm{q} 22), \operatorname{del}(9)(\mathrm{q} 13 \mathrm{q} 22)[\mathrm{n}]$ & 1 & {$[1]$} & 11 & 1 & $1(25)$ & $2(5.0)$ \\
\hline
\end{tabular}




\section{Journal of LABORATORY MEDICINE and QUALITY ASSURANCE}

Chang-Hun Park et al • 2014 Report on the External Quality Assessment

Table 2. Contineud

\begin{tabular}{|c|c|c|c|c|c|c|c|}
\hline \multirow{2}{*}{ Specimen } & \multirow{2}{*}{ Karyotype } & \multicolumn{4}{|c|}{ Grading } & \multirow{2}{*}{ Referee } & \multirow{2}{*}{ Participants } \\
\hline & & M & $S$ & A & $\mathrm{N}$ & & \\
\hline & 46,XY,t(8;9;21)(q22;q33;q22),del(9)(q22q34)[n] & $1]$ & 1 & 1 & 1 & 0 & $1(2.5)$ \\
\hline & $46, \mathrm{XY}, \mathrm{t}(8 ; 9 ; 21)(\mathrm{q} 23 ; \mathrm{q} 33 ; \mathrm{q} 22), \operatorname{del}(9)(\mathrm{q} 13 \mathrm{q} 22)[\mathrm{n}]$ & 10 & 1 & 1 & 11 & $1(25)$ & 0 \\
\hline & $46, \mathrm{XY}, \mathrm{t}(8 ; 9)(\mathrm{q} 22 ; \mathrm{q} 34), \operatorname{del}(9)(\mathrm{q} 22 \mathrm{q} 32)[\mathrm{n}]$ & 1 & 11 & 3 & 3 & 0 & $3(7.5)$ \\
\hline & $46, \mathrm{XY}, \mathrm{t}(8 ; 9)(\mathrm{q} 22 ; \mathrm{q} 33), \operatorname{del}(9)(\mathrm{q} 22 \mathrm{q} 32)[\mathrm{n}]$ & {$[1]$} & 11 & 3 & 3 & 0 & $2(5.0)$ \\
\hline & $46, \mathrm{XY}, \mathrm{t}(8 ; 9)(\mathrm{q} 22 ; \mathrm{q} 32), \operatorname{del}(9)(\mathrm{q} 22 \mathrm{q} 34)[\mathrm{n}]$ & $1]$ & 11 & 3 & 3 & 0 & $2(5.0)$ \\
\hline & $46, \mathrm{XY}, \mathrm{t}(8 ; 9)(\mathrm{q} 22 ; \mathrm{q} 34), \operatorname{del}(9)(\mathrm{q} 22 \mathrm{q} 34)[\mathrm{n}]$ & $1]$ & 1 & 3 & 3 & 0 & $2(5.0)$ \\
\hline & $46, \mathrm{XY}, \mathrm{t}(8 ; 9)(\mathrm{q} 22 ; \mathrm{q} 32), \operatorname{del}(9)(\mathrm{q} 13 \mathrm{q} 22)[\mathrm{n}]$ & {$[1]$} & 1 & 3 & 3 & 0 & $1(2.5)$ \\
\hline & $46, \mathrm{XY}, \mathrm{t}(8 ; 9)(\mathrm{q} 22 ; \mathrm{q} 34), \operatorname{del}(9)(\mathrm{q} 22)[\mathrm{n}]$ & [1] & 1 & 3 & 3 & 0 & $1(2.5)$ \\
\hline & $46, \mathrm{XY}, \mathrm{t}(8 ; 9)(\mathrm{q} 22 ; \mathrm{q} 34), \operatorname{del}(9)(\mathrm{q} 22 \mathrm{q} 33)[\mathrm{n}]$ & [1] & 1 & 3 & 3 & 0 & $1(2.5)$ \\
\hline & $46, \mathrm{XY}, \mathrm{t}(8 ; 9)(\mathrm{q} 21.2 ; \mathrm{q} 22), \operatorname{del}(9)(\mathrm{q} 13 \mathrm{q} 22)[\mathrm{n}]$ & [1] & 1 & 3 & 3 & 0 & $1(2.5)$ \\
\hline & $46, \mathrm{XY}, \mathrm{t}(8 ; 21)(\mathrm{q} 22 ; \mathrm{q} 22), \operatorname{del}(9)(\mathrm{q} 13 \mathrm{q} 22)[\mathrm{n}]$ & [1] & 1 & 3 & 3 & 0 & $1(2.5)$ \\
\hline & $46, \mathrm{XY}, \mathrm{t}(8 ; 9)(\mathrm{q} 22 ; \mathrm{q} 34), \operatorname{del}(9)(\mathrm{q} 22 \mathrm{q} 34), \operatorname{del}(21)(\mathrm{q} 21 \mathrm{q} 22)[\mathrm{n}]$ & [1] & 1 & 3 & 3 & 0 & $1(2.5)$ \\
\hline & $46, \mathrm{XY}, \mathrm{t}(8 ; 9)(\mathrm{q} 22 ; \mathrm{q} 34), \mathrm{t}(9 ; 21)(\mathrm{q} 31 ; \mathrm{q} 22)$ & 11 & 11 & 3 & 3 & 0 & $1(2.5)$ \\
\hline \multirow[t]{10}{*}{$14 \mathrm{CY}-10$} & $51, \mathrm{XY},+3,+7, \mathrm{t}(8 ; 14)(\mathrm{q} 24.1 ; \mathrm{q} 32),+10, \operatorname{del}(11)(\mathrm{q} 14 \mathrm{q} 23),+18,+18[\mathrm{n}]$ & $1]$ & 1 & [1] & 1 & $2(50)$ & $8(20.0)$ \\
\hline & $51, \mathrm{XY},+3,+7, \mathrm{t}(8 ; 14)(\mathrm{q} 24.1 ; \mathrm{q} 32),+10, \operatorname{del}(11)(\mathrm{q} 21 \mathrm{q} 23),+18,+18[\mathrm{n}]$ & 11 & 1 & [1] & 1 & 0 & $10(25.0)$ \\
\hline & $51, \mathrm{XY},+3,+7, \mathrm{t}(8 ; 14)(\mathrm{q} 24.1 ; \mathrm{q} 32),+10, \operatorname{del}(11)(\mathrm{q} 23),+18,+18[\mathrm{n}]$ & 11 & 1 & 1 & 1 & $2(50)$ & $6(15.0)$ \\
\hline & $51, \mathrm{XY},+3,+7, \mathrm{t}(8 ; 14)(\mathrm{q} 24.1 ; \mathrm{q} 32),+10, \operatorname{del}(11)(\mathrm{q} 13 \mathrm{q} 23),+18,+18[\mathrm{n}]$ & $1]$ & 1 & 1 & 1 & 0 & $7(17.5)$ \\
\hline & $51, \mathrm{XY},+3,+7, \mathrm{t}(8 ; 14)(\mathrm{q} 24.1 ; \mathrm{q} 32),+10, \operatorname{del}(11)(\mathrm{q} 22),+18,+18[\mathrm{n}]$ & 11 & 11 & 1 & 1 & 0 & $3(7.5)$ \\
\hline & $51, \mathrm{XY},+3,+7, \mathrm{t}(8 ; 14)(\mathrm{q} 24.1 ; \mathrm{q} 32),+10, \operatorname{del}(11)(\mathrm{q} 22 \mathrm{q} 23),+18,+18[\mathrm{n}]$ & 11 & 1 & {$[1]$} & 1 & 0 & $1(2.5)$ \\
\hline & $51, \mathrm{XY},+3,+7, \mathrm{t}(8 ; 14)(\mathrm{q} 24 ; \mathrm{q} 32),+10, \operatorname{del}(11)(\mathrm{q} 13 \mathrm{q} 22),+18,+18[\mathrm{n}]$ & {$[1]$} & 1 & 1 & 2 & 0 & $1(2.5)$ \\
\hline & $51, \mathrm{XY},+3,+7, \mathrm{t}(8 ; 14)(\mathrm{q} 24 ; \mathrm{q} 32),+10, \operatorname{del}(11)(\mathrm{q} 21),+18,+18[\mathrm{n}]$ & {$[1]$} & 11 & 1 & 2 & 0 & $1(2.5)$ \\
\hline & $51, \mathrm{XY},+3,+7,+10, \mathrm{t}(11 ; 14)(\mathrm{q} 23 ; \mathrm{q} 32),+18,+18[\mathrm{n}] / 51, \mathrm{idem}, \operatorname{del}(8)(\mathrm{q} 24.1)[\mathrm{n}]$ & $1]$ & 1 & 3 & 3 & 0 & $1(2.5)$ \\
\hline & $51, \mathrm{XY},+3,+7, \mathrm{t}(8 ; 11 ; 14)(\mathrm{q} 24.1 ; \mathrm{q} 23 ; \mathrm{q} 32),+10,+18,+18$ & $1]$ & $1]$ & 3 & 3 & 0 & $1(2.5)$ \\
\hline
\end{tabular}

Values are presented as number (\%).

Abbreviations: M, modal chromosome number; S, sex chromosome designation; A, recognition of abnormalities; N, karyotype nomenclature; $\square$, not graded; 1, good performance; 2, acceptable performance; 3, unacceptable performance.

다. 9월에 실시된 제2차 FISH검사정도관리에서는 1개 기관 이 하반기에 신규 등록하여 총 33개 기관에 발송하여 33개 기 관으로부터 결과회신을 받았다. FISH검사항목별 분석결과는 Table 3과 같다.

\section{2. 분자유전검사}

1) 참여기관 및 검사항목

2014년 1차 및 2차 외부정도관리에 참여한 기관은 각각 127 개, 130 개 기관이었다. 분자미생물검사는 human papilloma virus ( $\mathrm{HPV}$ ), 결핵균, $\mathrm{HBV}$ (정성, 정량), $\mathrm{HCV}$ (정성, 정량) 6 종류에 대해 시행하였다. 1차에서는 각각 41개, 109개, 11개, 110 개, 19 개, 59 개 기관이 참여하였고, 2 차에서는 각각 41 개, 112 개, 8 개, 111 개, 17 개, 61 개 기관이 참가하였다. 분자유전
검사는 multiple endocrine neoplasia 2와 Leber hereditary optic neuropathy 분자유전검사를 신규로 추가하여 혈액종양 5 종목, 고형종양 4종목, 선천성 유전질환 18 종목, 유전형검사 3 종목, 염기서열분석 1종목 4문항에 대해 시행하였다.

백혈병/림프종, JAK2, FMS-like tyrosine kinase 3 (FLT3)-ITD, FLT3-TKD, nucleophosmin (NPM1) 분자유 전검사는 1 차에서 각각 34 기관, 29 기관, 18 기관, 15 기관, 13 기 관이, 2 차에서 32 기관, 29 기관, 16 기관, 15 기관, 13 기관이 참 가하였다. KRAS, BRAF, EGFR, KIT 분자유전검사는 1차 에서 10 기관, 15 기관, 7 기관, 11 기관이 참가하였고, 2 차에서는 10 기관, 14 기관, 7 기관, 11 기관이 참가하였다.

BRCA1, BRCA2, TP53, ATP7B, FGFR3, GJB2, 분자 유전검사는 1 차에서 각각 12 기관, 12 기관, 7 기관, 5 기관, 7 기 
Journal of LABORATORY MEDICINE and QUALITY ASSURANCE

Chang-Hun Park et al • 2014 Report on the External Quality Assessment

Table 3. Distribution of the methods and probe types used for the FISH survey and results of participants during 2014

\begin{tabular}{|c|c|c|c|c|c|}
\hline Specimen & Intended responses & Manufacturer & Probe type & $\begin{array}{c}\text { No. of } \\
\text { laboratories }\end{array}$ & $\begin{array}{c}\text { Acceptable } \\
\text { response }\left(n / N^{*}, \%\right)\end{array}$ \\
\hline \multirow[t]{7}{*}{ 14CYF-01 } & Consistent with Trisomy 21 & Vysis & Single colour & 9 & $21 / 21(100)$ \\
\hline & & & Dual colour & 3 & \\
\hline & & & Other & 3 & \\
\hline & & CytoCell & Single colour & 1 & \\
\hline & & & Dual colour & 2 & \\
\hline & & Mirax & Single colour & 1 & \\
\hline & & & Others & 2 & \\
\hline \multirow[t]{5}{*}{ 14CYF-02 } & Deleted for the PWS/AS critical region & Vysis & Dual colour & 6 & $15 / 15(100)$ \\
\hline & & & Triple colour & 5 & \\
\hline & & CytoCell & Dual colour & 1 & \\
\hline & & Mirax & Dual colour & 2 & \\
\hline & & Kreatech & Dual colour & 1 & \\
\hline \multirow[t]{4}{*}{ 14CYF-03 } & Abnormal with $B C R / A B L 1$ fusion & Vysis & Dual fusion & 22 & $28 / 28(100)$ \\
\hline & & & Others & 3 & \\
\hline & & CytoCell & Dual fusion & 2 & \\
\hline & & Mirax & Dual fusion & 1 & \\
\hline \multirow[t]{3}{*}{ 14CYF-04 } & Abnormal with homozygous deletion of $C D K N 2 A$ & Vysis & Dual colour & 7 & $7 / 11(64)$ \\
\hline & & CytoCell & Dual colour & 3 & \\
\hline & & Mirax & Dual colour & 1 & \\
\hline \multirow[t]{4}{*}{ 14CYF-05 } & Abnormal with gain of $D 7 S 522$ & Vysis & Dual colour & 13 & $16 / 16(100)$ \\
\hline & & & Single colour & 1 & \\
\hline & & CytoCell & Dual colour & 1 & \\
\hline & & Mirax & Tri-colour & 1 & \\
\hline \multirow[t]{8}{*}{ 14CYF-08 } & Consistent with Trisomy 21 & Vysis & Single colour & 6 & $21 / 21(100)$ \\
\hline & & & Dual colour & 5 & \\
\hline & & & Single fusion & 1 & \\
\hline & & & Dual fusion & 4 & \\
\hline & & CytoCell & Single colour & 2 & \\
\hline & & & Dual colour & 1 & \\
\hline & & Mirax & Single colour & 1 & \\
\hline & & & Dual colour & 1 & \\
\hline \multirow[t]{4}{*}{ 14CYF-09 } & Mosaic XXX & Vysis & Dual colour & 17 & $21 / 22(95)$ \\
\hline & & & Single colour & 1 & \\
\hline & & CytoCell & Dual colour & 2 & \\
\hline & & Mirax & Dual colour & 2 & \\
\hline \multirow[t]{3}{*}{$14 \mathrm{CYF}-10$} & Abnormal with $P M L / R A R a$ fusion & Vysis & Dual fusion & 20 & $25 / 25(100)$ \\
\hline & & & Others & 2 & \\
\hline & & CytoCell & Dual fusion & 3 & \\
\hline
\end{tabular}


Journal of LABORATORY MEDICINE and QUALITY ASSURANCE

Chang-Hun Park et al • 2014 Report on the External Quality Assessment

Table 3. Contineud

\begin{tabular}{|c|c|c|c|c|c|}
\hline Specimen & Intended responses & Manufacturer & Probe type & $\begin{array}{c}\text { No. of } \\
\text { laboratories }\end{array}$ & $\begin{array}{c}\text { Acceptable } \\
\text { response }\left(n / N^{*}, \%\right)\end{array}$ \\
\hline \multirow[t]{4}{*}{ 14CYF-11 } & Abnormal with loss of D13S319 & Vysis & Dual colour & 4 & $15 / 15(100)$ \\
\hline & & & Single colour & 2 & \\
\hline & & CytoCell & Dual colour & 5 & \\
\hline & & Mirax & Dual colour & 4 & \\
\hline \multirow[t]{5}{*}{ 14CYF-12 } & Abnormal with loss of TP53 & Vysis & Dual colour & 10 & $24 / 24(100)$ \\
\hline & & & Dual fusion & 1 & \\
\hline & & CytoCell & Dual colour & 5 & \\
\hline & & Mirax & Dual colour & 7 & \\
\hline & & Kreatech & Dual colour & 1 & \\
\hline
\end{tabular}

Abbreviation: labs, laboratories.

*Indicates the acceptable number/total number of participants.

Table 4. HPV detection methods in the molecular genetics test survey in 2014

\begin{tabular}{|c|c|c|}
\hline Manufacturer & Kit & No. of participants \\
\hline 1 st trial & & 47 \\
\hline BioCore & HPV screening PCR kit & 2 \\
\hline BioCore & HPV 16/18 PCR kit & 1 \\
\hline BioMedLab & HPV DNA chip & 10 \\
\hline Qiagen & HC2 HPV DNA test & 17 \\
\hline Seegene & Seeplex HPV 4A ACE screening & 5 \\
\hline Others & Others & 12 \\
\hline 2nd trial & & 46 \\
\hline BioCore & HPV screening PCR kit & 1 \\
\hline BioMedLab & HPV DNA chip & 7 \\
\hline Goodgene & HPV genotyping chip & 1 \\
\hline Qiagen & HC2 HPV DNA test & 17 \\
\hline Seegene & Seeplex HPV 4A ACE screening & 1 \\
\hline Seegene & Anyplex II HPV28 & 6 \\
\hline GeneMatrix & HPV genotyping papillotype & 4 \\
\hline Roche & COBAS 4800 HPV realtime PCR kit & 2 \\
\hline Infopia & GeneFinder HPV liquid bead microarray & 3 \\
\hline Biometrix Technology & HPV 9G DNA kit & 2 \\
\hline Others & Others & 2 \\
\hline
\end{tabular}

Abbreviation: HPV, human papilloma virus.

관, 9 기관, 13 기관이 참가하였으며, 2 차에서 12 기관, 12 기관, 7기관, 5 기관, 7 기관, 9 기관, 12 기관이 참가하였다. $\mathrm{HD}, \mathrm{SCA}$, SBMA, mitochondrial encephalopathy with lactic acidosis and stroke like episodes (MELAS), myoclonic epilepsy ragged red fibre (MERRF), Prader-Willi/Angelman syn- drome (PWS/AS), Duchenne muscular dystrophy (DMD), spinal muscular atrophy (SMA) 분자유전검사는 1차에서 각각 4 기관, 5 기관, 3 기관, 5 기관, 4 기관, 4 기관, 5 기관, 5 기관 이 참가하였고 2 차에서 4 기관, 5 기관, 3 기관, 5 기관, 4 기관, 4 기관, 5 기관, 5 기관이 참가하였다. Apolipoprotein $\mathrm{E}(\mathrm{APOE})$, 


\section{Journal of LABORATORY MEDICINE and QUALITY ASSURANCE}

Chang-Hun Park et al • 2014 Report on the External Quality Assessment

methylenetetrahydrofolate reductase (MTHFR), ABO, $F M R 1, \mathrm{DNA}$ 염기서열분석, RET, LHON 분자유전검사는 1 차에서 각각 36 기관, 14 기관, 10 기관, 7 기관, 17 기관, 5 기관, 5 기관이 참가하였으며, 2 차에서 각각 35 기관, 13 기관, 9 기관, 7 기관, 17 기관, 6 기관, 5 기관이 참가하였다.

\section{2) 검사방법}

분자미생물검사의 검사법과 시약은 Tables 4-9과 같다. 결 핵균검사에서 키트 사용기관의 비율은 1999년 66\%, 2001 년 77\%, 2002년 93\%, 2003년 94\%, 2004년 90\%, 2005년도 90\%, 2006년도 90\%, 2007년도 92\%, 2008년도 87\%, 2009 년도 80\%, 2010년도 95\%, 2011년 92\%, 2012년 91\%, 2013 년 94\%였으며, 2014년은 97\%로 전년도에 비하여 소폭 증가 하였다. HPV검사법은 Qiagen (Digene) Hybrid Capture 2가
가장 많이 사용되었으며 MTB는 LG Lifescience AdvanSure TB/NTM real-time PCR이 가장 많이 사용되었다. HBV, $\mathrm{HCV}$ 정량검사법은 Roche사의 kit가 가장 많이 사용되었으며, 그 다음으로 Abbott사의 kit가 많이 사용되었다.

\section{3) 검사결과}

백혈병/림프종 분자유전검사는 두 문항의 검체로 구성하여 평가하였다. 1 차에서는 $B C R-A B L 1$ 재배열과 PML-RARA 재배열 검체를 2 차에서는 $P M L-R A R A$ 재배열과 TEL-AML1 재배열 검체로 구성하였다. 1 차 평가에서 $B C R-A B L 1$ 재배 열 문항에 대하여 34 개 기관 중 32 개 기관이 예상 결과와 일 치하는 결과를 보고하였고 PML-RARA 재배열 문항은 29 개 기관 중 19 개 기관이 예상결과와 일치한 결과를 보고하였 고 10 개 기관에서는 예상과 달리 음성으로 보고하여 평가에

Table 5. Mycobacterium tuberculosis detection methods in the molecular genetics test survey in 2014

\begin{tabular}{|c|c|c|}
\hline Manufacturer & Kit & No. of participants \\
\hline 1st trial & & 115 \\
\hline Roche & COBAS TaqMan MTB test & 24 \\
\hline Biosewoom & MTB PCR kit & 3 \\
\hline Biosewoom & NTM\&MTB PCR Kit & 9 \\
\hline Seegene & Seeplex MTB nested ACE detection & 4 \\
\hline Seegene & Anyplex MTB/NTM real-time detection & 6 \\
\hline Biocore & TB/NTM real time PCR & 2 \\
\hline Bioneer & MTB real-time PCR & 14 \\
\hline LG Lifescience & AdvanSure TB/NTM real-time PCR & 41 \\
\hline YD Diagnostics & YD diagnostics real TB-Tag & 1 \\
\hline Cepheid & Gene Xpert MTB/RIF kit & 4 \\
\hline GREEN CROSS & MTB/NTM detection kit & 4 \\
\hline Others & Others & 3 \\
\hline 2nd trial & & 122 \\
\hline Roche & COBAS TaqMan MTB test & 23 \\
\hline Biosewoom & MTB PCR kit & 3 \\
\hline Biosewoom & NTM\&MTB PCR Kit & 11 \\
\hline Seegene & Seeplex MTB nested ACE detection & 2 \\
\hline Seegene & Anyplex MTB/NTM real-time detection & 7 \\
\hline Biocore & TB/NTM real time PCR & 2 \\
\hline Bioneer & MTB\&NTM real-time PCR & 7 \\
\hline Bioneer & MTB real-time PCR & 8 \\
\hline LG Lifescience & AdvanSure TB/NTM real-time PCR & 42 \\
\hline YD Diagnostics & YD Diagnostics Real TB-Tag & 1 \\
\hline Cepheid & Gene Xpert MTB/RIF kit & 7 \\
\hline GREEN CROSS & MTB/NTM detection kit & 1 \\
\hline AmpliSens & MTC-FEP & 1 \\
\hline Others & Others & 5 \\
\hline
\end{tabular}

Abbreviations: MTB, Mycobacterium tuberculosis; NTM, nontuberculous mycobacteria; TB, Tuberculosis. 


\section{Journal of LABORATORY MEDICINE and QUALITY ASSURANCE}

Chang-Hun Park et al • 2014 Report on the External Quality Assessment

Table 6. HBV detection methods in the molecular genetics test survey of trial 1 in 2014

\begin{tabular}{lllr}
\hline \multicolumn{1}{c}{ Test } & Manufacturer & \multicolumn{1}{c}{ Method } & No. of participants \\
\hline Qualitative & BioCore & HBV PCR kit & 2 \\
& DiaProbe & Opti One step HBV test & 1 \\
& Roche & COBAS TaqMan & 3 \\
& Novartis & Procleix ultrio plus assay & 4 \\
Others & & Others & 11 \\
Quantitative & Roche & & 68 \\
& Bayer & COBAS TaqMan & 1 \\
& Artus (Qiagen) & VERSANT HBV DNA assay & 4 \\
& Abbott & HBV real-time PCR kit & 1 \\
& Biosewoom & HBV real-time PCR kit & 1 \\
& LG Lifescience & HBV real-time PCR kit & 1 \\
& Bioneer & AdvanSure HBV real-time PCR kit & 111 \\
\hline
\end{tabular}

Abbreviation: HBV, hepatitis B virus.

Table 7. HBV detection methods in the molecular genetics test survey of trial 2 in 2014

\begin{tabular}{|c|c|c|c|}
\hline Test & Manufacturer & Method & No. of participants \\
\hline \multirow[t]{5}{*}{ Qualitative } & BioCore & HBV PCR kit & 1 \\
\hline & DiaProbe & Opti one step HBV test & 1 \\
\hline & Roche & COBAS TaqMan & 4 \\
\hline & Novartis & Procleix ultrio plus assay & 1 \\
\hline & Others & Others & 1 \\
\hline Total & & & 8 \\
\hline \multirow[t]{7}{*}{ Quantitative } & Roche & COBAS TaqMan & 71 \\
\hline & Artus (Qiagen) & HBV real-time PCR kit & 3 \\
\hline & Abbott & HBV real-time PCR kit & 21 \\
\hline & Biosewoom & HBV real-time PCR kit & 1 \\
\hline & LG Lifescience & AdvanSure HBV real-time PCR kit & 8 \\
\hline & Bioneer & HBV quantitative kit & 7 \\
\hline & Other & Other & 1 \\
\hline Total & & & 112 \\
\hline
\end{tabular}

Abbreviation: HBV, hepatitis B virus.

서 제외하였다. 2차 평가에서는 PML-RARA 재배열과 TEL$A M L 1$ 재배열 모두에서 모든 기관에서 예상결과와 일치한 결 과를 보고하였다. JAK2, FLT3-ITD, NPM1, KRAS, BRAF, EGFR, KIT, BRCA2, TP53, ATP7B, FGFR3, TGFBI, SCA, SBMA, MELAS, MERRF, PWS/AS, APOE, ABO, $F M R 1, R E T, \mathrm{LHON}$ 의 항목은 참여한 모든 기관이 예상결과 와 일치한 결과를 보고하였다.

FLT3-TKD는 1차에서 4개 기관이 예상결과와 불일치하였
으나 3 개 기관은 검사범위의 상이함을 이유로 평가에서 제외 하였다, NPM1과 BRCA1은 2차에서 1개 기관이, $D M D$ 는 2 차에서 1 개 기관이 결과해석에서 예상결과와 불일치하였다. $M T H F R$ 는 2차에서 2개 기관이 결과해석에서 예상결과와 불 일치하였으며 GJB2는 1 차에서 1 개 기관이 변이를 찾지 못하 였다. $\mathrm{HD}$ 는 1 차에서 결과해석에서 1 개 기관이 normal로, 3 개 기관이 intermediate allele로 보고하였고 SMA는 2차에서 1 개 기관이 예상과 다른 결과를 보고하였다. 


\section{Journal of LABORATORY MEDICINE and QUALITY ASSURANCE}

Chang-Hun Park et al • 2014 Report on the External Quality Assessment

Table 8. HCV detection methods in the molecular genetics test survey of trial 1 in 2014

\begin{tabular}{|c|c|c|c|}
\hline Specimen & Manufacturer & Method & No. of participants \\
\hline \multirow[t]{6}{*}{ Qualitative } & Roche & AMPLICOR HCV test & 5 \\
\hline & Biosewoom & HCV real-time PCR kit & 1 \\
\hline & BioCore & HCV PCR kit & 1 \\
\hline & Abbott & HCV real-time PCR kit & 5 \\
\hline & Seegene & HepaTrio real-time PCR test & 1 \\
\hline & Others & Others & 5 \\
\hline Total & & & 18 \\
\hline \multirow[t]{4}{*}{ Quantitative } & Roche & COBAS TaqMan & 44 \\
\hline & Abbott & HCV real-time PCR kit & 11 \\
\hline & Biosewoom & HCV real-time PCR kit & 1 \\
\hline & Artus (Qiagen) & HCV real-time PCR kit & 2 \\
\hline Total & & & 58 \\
\hline
\end{tabular}

Abbreviation: $\mathrm{HCV}$, hepatitis $\mathrm{C}$ virus.

Table 9. HCV detection methods in the molecular genetics test survey of trial 2 in 2014

\begin{tabular}{|c|c|c|c|}
\hline Specimen & Manufacturer & Method & No. of participants \\
\hline \multirow[t]{6}{*}{ Qualitative } & Roche & AMPLICOR HCV test & 7 \\
\hline & Biosewoom & HCV real-time PCR kit & 1 \\
\hline & Abbott & HCV real-time PCR kit & 5 \\
\hline & Seegene & HepaTrio real-time PCR test & 1 \\
\hline & Novartis & Procleix ultrio plus assay & 1 \\
\hline & Others & Others & 2 \\
\hline Total & & & 17 \\
\hline \multirow[t]{5}{*}{ Quantitative } & Roche & AMPLICOR HCV MONITOR test & 1 \\
\hline & Roche & COBAS TaqMan & 46 \\
\hline & Abbott & HCV real-time PCR kit & 12 \\
\hline & Biosewoom & HCV real-time PCR kit & 1 \\
\hline & Artus (Qiagen) & HCV real-time PCR kit & 1 \\
\hline Total & & & 61 \\
\hline
\end{tabular}

Abbreviation: $\mathrm{HCV}$, hepatitis $\mathrm{C}$ virus.

DNA 염기서열분석항목은 case와 reference sequence 파일 을 제공하고 각 기관에서 sequence reading tool을 이용하여 염기서열을 판독하도록 하였다. DNA 염기서열판독의 경우 1 차에서는 FANCA, MEN1, FBN1, RB1 유전자에 대하여 문항 을 구성하였고, 2차에서는 $K C N Q 1, M E C P 2, N F 1, S C N 5 A$ 유전자에 대하여 문항을 구성하였다. 1 차에 참여한 17 개 기관 중에서 MEN1 유전자는 2개 기관이 예상과 다른 결과를 보고 하여 unacceptable한 결과를 보였다. 2차에 참여한 17 개 기 관 중에서 $M E C P 2$ 유전자는 3 개 기관이 예상과 다른 결과를 보고하여 unacceptable한 결과를 보였으며, SCN5A 유전자
에서 변이 해석에 있어서 8개의 기관이 previously reported, cause of disorder로 보고하였으며, 9개의 기관이 previously reported, variant with unknown significance로 보고하여 평 가에서 제외하였다.

분자미생물은 $\mathrm{HPV}, \mathrm{MTB}, \mathrm{HBV}$ (정성, 정량) $\mathrm{HCV}$ (정성, 정 량)항목에서 모든 기관에서 예상결과와 일치하는 결과를 보 였다. 각 기관별 보고결과를 분석한 통계는 Table 10 과 같다. $\mathrm{HBV}$ 와 $\mathrm{HCV}$ 정량검사를 실시한 기관에서 보고한 정량검사 결과는 Tables $11-14$ 와 같다. 
Journal of LABORATORY MEDICINE and QUALITY ASSURANCE

Chang-Hun Park et al • 2014 Report on the External Quality Assessment

Table 10. Results of the molecular genetics test survey during 2014

\begin{tabular}{|c|c|c|c|c|c|c|}
\hline Tests & $\begin{array}{l}\text { Specimens } \\
\text { of 1st trial }\end{array}$ & $\begin{array}{l}\text { Intended } \\
\text { responses }\end{array}$ & $\begin{array}{c}\text { Acceptable } \\
\text { response }\left(\mathbf{n} / \mathbf{N}^{\star}\right)\end{array}$ & $\begin{array}{l}\text { Specimens } \\
\text { of } 2 \text { nd trial }\end{array}$ & $\begin{array}{l}\text { Intended } \\
\text { responses }\end{array}$ & $\begin{array}{c}\text { Acceptable } \\
\text { response }\left(n / N^{*}\right)\end{array}$ \\
\hline HPV & MD 1401-A & Positive & $41 / 41$ & MD 1402-A & Negative & $41 / 41$ \\
\hline \multirow[t]{2}{*}{ M. tuberculosis } & MD 1401-C & Positive & $109 / 109$ & MD 1402-C & Negative & $112 / 112$ \\
\hline & MD 1401-D & NTM & $109 / 109$ & MD 1402-D & Positive & $112 / 112$ \\
\hline HBV detection & MD 1401-G & Normal pooled plasma & $11 / 11$ & MD 1402-G & $\begin{array}{l}\text { Normal pooled } \\
\text { plasma }\end{array}$ & $8 / 8$ \\
\hline \multirow[t]{3}{*}{ HBV quantification } & MD 1401-H & HBV high positive & $110 / 110$ & MD 1402-H & HBV high positive & $111 / 111$ \\
\hline & MD 1401-I & Normal pooled plasma & $110 / 110$ & MD 1402-I & HBV low positive & $111 / 111$ \\
\hline & MD 1401-J & HBV low positive & $110 / 110$ & MD 1402-J & Normal pooled plasma & $111 / 111$ \\
\hline \multirow[t]{3}{*}{ HCV quantification } & MD 1401-N & Normal pooled plasma & $58 / 58$ & MD 1402-N & $\begin{array}{l}\text { Normal pooled } \\
\text { plasma }\end{array}$ & $61 / 61$ \\
\hline & MD 1401-O & HCV high positive & $58 / 58$ & MD 1402-O & HCV high positive & $61 / 61$ \\
\hline & MD 1401-P & HCV low positive & $58 / 58$ & MD 1402-P & HCV low positive & $61 / 61$ \\
\hline \multirow{2}{*}{$\begin{array}{l}\text { Leukaemia/ } \\
\text { Lymphoma }\end{array}$} & MD 1401-01 & $B C R / A B L 1$ positive & $32 / 34$ & MD 1402-01 & $P M L / R A R A$ positive & $32 / 32$ \\
\hline & MD 1401-02 & $P M L / R A R A$ positive & $\begin{array}{c}28 / 29 \\
\text { Valuation } \\
\text { exception }\end{array}$ & MD 1402-02 & TEL/AML1 positive & $26 / 26$ \\
\hline$J A K 2$ & MD 1401-03 & Mutation detected & $29 / 29$ & MD 1402-03 & Mutation detected & $29 / 29$ \\
\hline NPM1 & MD 1401-10 & Mutation not detected & $13 / 13$ & MD $1402-10$ & Mutation not detected & $13 / 13$ \\
\hline \multirow[t]{2}{*}{$K R A S$} & MD 1401-11 & Mutation detected & $10 / 10$ & MD 1402-11 & Mutation detected & $10 / 10$ \\
\hline & MD 1401-12 & Mutation not detected & $10 / 10$ & MD 1402-12 & Mutation not detected & $10 / 10$ \\
\hline \multirow[t]{2}{*}{$B R A F$} & MD 1401-13 & Mutation detected & $15 / 15$ & MD 1402-13 & Mutation detected & $14 / 14$ \\
\hline & MD 1401-14 & Mutation not detected & $15 / 15$ & MD 1402-14 & Mutation not detected & $14 / 14$ \\
\hline \multirow[t]{2}{*}{ EGFR } & MD 1401-15 & Mutation not detected & $7 / 7$ & MD 1402-15 & Mutation detected & $7 / 7$ \\
\hline & MD 1401-16 & Mutation detected & $7 / 7$ & MD 1402-16 & Mutation not detected & $7 / 7$ \\
\hline \multirow[t]{2}{*}{ KIT } & MD 1401-17 & Mutation not detected & $11 / 11$ & MD 1402-17 & Mutation not detected & $11 / 11$ \\
\hline & MD 1401-18 & Mutation detected & $11 / 11$ & MD 1402-18 & Mutation detected & $11 / 11$ \\
\hline \multirow[t]{2}{*}{$B R C A 1$} & MD 1401-19 & Mutation detected & $12 / 12$ & MD 1402-19 & Mutation detected & $11 / 12$ \\
\hline & MD 1401-20 & Mutation not detected & $12 / 12$ & MD 1402-20 & Mutation not detected & $12 / 12$ \\
\hline \multirow[t]{2}{*}{$B R C A 2$} & MD 1401-19 & Mutation not detected & $12 / 12$ & MD 1402-19 & Mutation not detected & $12 / 12$ \\
\hline & MD 1401-20 & Mutation detected & $12 / 12$ & MD 1402-20 & Mutation detected & $12 / 12$ \\
\hline \multirow[t]{2}{*}{ BRCA2 } & MD 1401-19 & Mutation not detected & $12 / 12$ & MD 1402-19 & Mutation not detected & $12 / 12$ \\
\hline & MD 1401-20 & Mutation detected & $12 / 12$ & MD 1402-20 & Mutation detected & $12 / 12$ \\
\hline
\end{tabular}

(Continued to the next page) 
Journal of LABORATORY MEDICINE and QUALITY ASSURANCE

Chang-Hun Park et al • 2014 Report on the External Quality Assessment

Table 10. Continued

\begin{tabular}{|c|c|c|c|c|c|c|}
\hline Tests & $\begin{array}{l}\text { Specimens } \\
\text { of } 1 \text { st trial }\end{array}$ & $\begin{array}{l}\text { Intended } \\
\text { responses }\end{array}$ & $\begin{array}{c}\text { Acceptable } \\
\text { response }\left(\mathbf{n} / \mathrm{N}^{\star}\right)\end{array}$ & $\begin{array}{l}\text { Specimens } \\
\text { of } 2 \text { nd trial }\end{array}$ & $\begin{array}{l}\text { Intended } \\
\text { responses }\end{array}$ & $\begin{array}{c}\text { Acceptable } \\
\text { response }\left(n / N^{*}\right)\end{array}$ \\
\hline TP53 & MD 1401-21 & Mutation detected & $7 / 7$ & MD 1402-21 & Mutation not detected & $7 / 7$ \\
\hline \multirow[t]{2}{*}{$A T P 7 B$} & MD 1401-23 & Mutation not detected & $5 / 5$ & MD 1402-23 & Mutation not detected & $5 / 5$ \\
\hline & MD 1401-24 & Mutation detected & $5 / 5$ & MD 1402-24 & Mutation detected & $5 / 5$ \\
\hline Achondroplasia & MD 1401-25 & Mutation detected & $7 / 7$ & MD 1402-25 & Mutation detected & $7 / 7$ \\
\hline \multirow[t]{2}{*}{ GJB2 } & MD 1401-27 & Variant detected & $8 / 9$ & MD 1402-27 & Variant detected & $9 / 9$ \\
\hline & MD 1401-28 & Mutation not detected & $9 / 9$ & MD 1402-28 & Mutation not detected & $9 / 9$ \\
\hline \multirow[t]{2}{*}{ TGFBI } & MD 1401-29 & Mutation not detected & $13 / 13$ & MD 1402-29 & Mutation not detected & $12 / 12$ \\
\hline & MD 1401-30 & Mutation detected & $13 / 13$ & MD 1402-30 & Mutation detected & $12 / 12$ \\
\hline MEN2 & MD 1401-31 & Mutation detected & Educational & MD 1402-31 & Mutation detected & Educational \\
\hline \multirow[t]{2}{*}{ SCA } & MD 1401-35 & SCA negative & $5 / 5$ & MD 1402-35 & SCA negative & $5 / 5$ \\
\hline & MD 1401-36 & SCA positive & $5 / 5$ & MD 1402-36 & SCA positive & $5 / 5$ \\
\hline \multirow[t]{2}{*}{ SBMA } & MD 1401-37 & SBMA positive & $3 / 3$ & MD 1402-37 & SBMA positive & $3 / 3$ \\
\hline & MD 1401-38 & SBMA negative & $3 / 3$ & MD 1402-38 & SBMA negative & $3 / 3$ \\
\hline \multirow[t]{2}{*}{ LHON } & MD 1401-39 & Mutation detected & Educational & MD 1402-39 & Mutation detected & Educational \\
\hline & MD 1401-40 & Mutation not detected & Educational & MD $1402-40$ & Mutation not detected & Educational \\
\hline \multirow[t]{2}{*}{ MELAS } & MD 1401-41 & Mutation not detected & $5 / 5$ & MD 1402-41 & Mutation not detected & $5 / 5$ \\
\hline & MD 1401-42 & Mutation detected & $5 / 5$ & MD $1402-42$ & Mutation detected & $5 / 5$ \\
\hline MERRF & MD 1401-43 & Mutation detected & $4 / 4$ & MD 1402-43 & Mutation detected & $4 / 4$ \\
\hline SMA & MD 1401-50 & SMA deletion negative & $5 / 5$ & MD 1402-50 & SMA deletion negative & $5 / 5$ \\
\hline APOE genotype & MD 1401-51 & APOE $\varepsilon 2 / \varepsilon 3$ genotype & $36 / 36$ & MD 1402-51 & $A P O E \varepsilon 2 / \varepsilon 3$ genotype & $35 / 35$ \\
\hline MTHFR genotype & MD 1401-52 & $\begin{array}{l}\text { 677C/C homozygous } \\
\text { normal }\end{array}$ & $14 / 14$ & MD 1402-52 & $\begin{array}{l}677 \mathrm{C} / \mathrm{T} \text { heterozygous } \\
\text { variant }\end{array}$ & $11 / 13$ \\
\hline ABO genotype & MD 1401-53 & Cis-AB/O genotype & $10 / 10$ & MD 1402-53 & A/O genotype & $9 / 9$ \\
\hline \multirow[t]{2}{*}{ FMR1 } & MD 1401-54 & Full-mutation & $7 / 7$ & MD 1402-54 & Pre-mutation & $7 / 7$ \\
\hline & MD 1401-55 & Pre-mutation & $7 / 7$ & MD 1402-55 & Normal & $7 / 7$ \\
\hline \multirow[t]{4}{*}{ DNA sequencing } & SEC 1401-01 & FANCA mutation & $17 / 17$ & SEC 1402-01 & KCNQ1 mutation & $17 / 17$ \\
\hline & SEC 1401-02 & MEN1 mutation & $15 / 17$ & SEC $1402-02$ & MECP2 mutation & $14 / 17$ \\
\hline & SEC 1401-03 & FBN1 mutation & $17 / 17$ & SEC 1402-03 & NF1 mutation & $17 / 17$ \\
\hline & SEC 1401-04 & RB1 mutation & $17 / 17$ & SEC 1402-04 & SCN5A mutation & $\begin{array}{l}\text { Valuation } \\
\text { exception }\end{array}$ \\
\hline
\end{tabular}

Abbreviations: HPV, human papilloma virus; HBV, hepatitis B virus; HCV, hepatitis C virus; NTM, nontuberculous mycobacteria; MEN2, multiple endocrine neoplasia 2; HD, Huntington disease; SCA, spinocerebellar ataxia; SBMA, spinal and bulbar muscular atrophy; LHON, Leber hereditary optic neuropathy; MELAS, mitochondrial encephalomyopathy, lactic acidosis, and stroke-like episodes; MERRF, myoclonic epilepsy with ragged red fibres; PWS/AS, Prader-Willi/Angelman syndrome; DMD, Duchenne muscular dystrophy; SMA, spinal muscular atrophy.

${ }^{\star}$ Indicates the acceptable numbers/total numbers of participants.

www.jlmqa.org J Jab Med Qual Assur 2015;37:64-83 


\section{Journal of LABORATORY MEDICINE and QUALITY ASSURANCE}

Chang-Hun Park et al • 2014 Report on the External Quality Assessment

Table 11. Result of HBV quantification in the survey of trial 1 in 2014

\begin{tabular}{|c|c|c|c|c|c|c|}
\hline Specimen & Method & $\begin{array}{c}\text { No. of } \\
\text { participants }\end{array}$ & $\begin{array}{c}\text { Minimum } \\
(\mathrm{IU} / \mathrm{mL})\end{array}$ & $\begin{array}{c}\text { Maximum } \\
(\mathrm{IU} / \mathrm{mL})\end{array}$ & $\begin{array}{c}\text { Mean } \\
(\mathrm{IU} / \mathrm{mL})\end{array}$ & $\begin{array}{c}\mathrm{SD} \\
(\mathrm{IU} / \mathrm{mL})\end{array}$ \\
\hline \multirow[t]{7}{*}{ MD 1401-H } & Roche COBAS TaqMan & 68 & $8,250,000$ & $1,517,740,783$ & $38,581,031$ & $182,827,024$ \\
\hline & Bayer VERSANT HBV DNA assay & 1 & $8,290,000$ & $8,290,000$ & & \\
\hline & Artus (Qiagen) HBV real-time PCR Kit & 4 & $15,114,414$ & $20,000,000$ & & \\
\hline & Abbott HBV real-time PCR kit & 20 & $8,608,277$ & $34,788,210$ & $19,683,479$ & $5,544,059$ \\
\hline & Biosewoom HBV real-time PCR Kit & 1 & $17,200,000$ & $17,200,000$ & & \\
\hline & LG Lifescience AdvanSure HBV, real-time PCR kit & 10 & $11,590,000$ & $26,800,000$ & $15,669,000$ & $4,299,940$ \\
\hline & Bioneer HBV quantitative kit & 7 & $5,650,000$ & $19,300,000$ & $10,190,000$ & $4,345,654$ \\
\hline MD 1401-I & Not detected & 110 & & & & \\
\hline \multirow[t]{7}{*}{ MD 1401-J } & Roche COBAS TaqMan & 68 & 173 & $16,182,208$ & 384,897 & $1,930,191$ \\
\hline & Bayer VERSANT HBV DNA assay & 1 & 157,000 & 157,000 & & \\
\hline & Artus (Qiagen) HBV real-time PCR kit & 4 & 171,553 & 218,000 & & \\
\hline & Abbott HBV real-time PCR kit & 20 & 95,514 & 201,003 & 137,717 & 24,796 \\
\hline & Biosewoom HBV real-time PCR kit & 1 & 187,000 & 187,000 & & \\
\hline & LG Lifescience AdvanSure HBV, real-time PCR kit & 10 & 79,800 & 270,700 & 142,880 & 49,794 \\
\hline & Bioneer HBV quantitative kit & 7 & 74,000 & 226,000 & 142,343 & 45,072 \\
\hline
\end{tabular}

Abbreviation: HBV, hepatitis B virus.

Table 12. Result of HBV quantification in the survey of trial 2 in 2014

\begin{tabular}{|c|c|c|c|c|c|c|}
\hline Specimen & Method & $\begin{array}{c}\text { No. of } \\
\text { participants }\end{array}$ & $\begin{array}{c}\text { Minimum } \\
(\mathrm{IU} / \mathrm{mL})\end{array}$ & $\begin{array}{c}\text { Maximum } \\
(\mathrm{IU} / \mathrm{mL})\end{array}$ & $\begin{array}{c}\text { Mean } \\
(\mathrm{IU} / \mathrm{mL})\end{array}$ & $\begin{array}{c}\mathrm{SD} \\
(\mathrm{IU} / \mathrm{mL})\end{array}$ \\
\hline \multirow[t]{7}{*}{ MD 1402-H } & Roche COBAS TaqMan & 71 & 300,000 & $110,000,000$ & $40,918,045$ & $16,944,859$ \\
\hline & Artus (Qiagen) HBV real-time PCR kit & 3 & $13,700,000$ & $32,311,760$ & & \\
\hline & Abbott HBV real-time PCR kit & 21 & $20,218,250$ & $75,857,758$ & $38,002,995$ & $15,023,284$ \\
\hline & Biosewoom HBV real-time PCR kit & 1 & $37,700,000$ & $37,700,000$ & & \\
\hline & LG Lifescience AdvanSure HBV, real-time PCR kit & 8 & $20,300,000$ & $42,070,000$ & & \\
\hline & Bioneer HBV quantitative kit & 7 & $12,800,000$ & $40,400,000$ & & \\
\hline & Other & 1 & $10,266,846$ & $10,266,846$ & & \\
\hline \multirow[t]{7}{*}{ MD 1402-I } & Roche COBAS TaqMan & 71 & 521,535 & $1,920,000$ & $1,088,628$ & 266,690 \\
\hline & Artus (Qiagen) HBV real-time PCR kit & 3 & 927,546 & $1,645,180$ & & \\
\hline & Abbott HBV real-time PCR kit & 21 & 702,687 & $2,157,605$ & $1,173,483$ & 381,486 \\
\hline & Biosewoom HBV real-time PCR kit & 1 & $2,220,000$ & $2,220,000$ & & \\
\hline & LG Lifescience AdvanSure HBV, real-time PCR kit & 8 & 773,700 & $1,726,000$ & & \\
\hline & Bioneer HBV quantitative kit & 7 & 758,000 & $1,910,000$ & & \\
\hline & Other & 1 & $1,247,312$ & $1,247,312$ & & \\
\hline MD 1402-J & Not detected & 111 & & & & \\
\hline
\end{tabular}

Abbreviation: HBV, hepatitis B virus. 


\section{Journal of LABORATORY MEDICINE and QUALITY ASSURANCE}

Chang-Hun Park et al • 2014 Report on the External Quality Assessment

Table 13. Result of HCV quantification in the survey of trial 1 in 2014

\begin{tabular}{|c|c|c|c|c|c|c|}
\hline Specimen & Method & $\begin{array}{c}\text { No. of } \\
\text { participants }\end{array}$ & $\begin{array}{c}\text { Minimum } \\
(\mathrm{IU} / \mathrm{mL})\end{array}$ & $\begin{array}{c}\text { Maximum } \\
(\mathrm{IU} / \mathrm{mL})\end{array}$ & $\begin{array}{c}\text { Mean } \\
(\mathrm{IU} / \mathrm{mL})\end{array}$ & $\begin{array}{c}\mathrm{SD} \\
(\mathrm{IU} / \mathrm{mL})\end{array}$ \\
\hline MD 1401-N & Not detected & 58 & & & & \\
\hline \multirow[t]{4}{*}{ MD 1401-O } & Roche COBAS TaqMan & 44 & 231,500 & $2,207,875$ & 413,862 & 308,096 \\
\hline & Abbott HCV real-time PCR kit & 11 & 306,299 & 936,718 & 452,720 & 162,492 \\
\hline & Biosewoom HCV real-time PCR kit & 1 & 137,000 & 137,000 & & \\
\hline & Artus (Qiagen) HCV real-time PCR kit & 2 & 466,177 & 715,264 & & \\
\hline \multirow[t]{4}{*}{ MD 1401-P } & Roche COBAS TaqMan & 44 & 7,370 & 41,342 & 12,565 & 5,317 \\
\hline & Abbott HCV real-time PCR kit & 11 & 5,286 & 17,632 & 9,223 & 3,039 \\
\hline & Biosewoom HCV real-time PCR kit & 1 & 137,000 & 137,000 & & \\
\hline & Artus (Qiagen) HCV real-time PCR kit & 2 & 15,762 & 20,265 & & \\
\hline
\end{tabular}

Abbreviation: $\mathrm{HCV}$, hepatitis $\mathrm{C}$ virus.

Table 14. Result of HCV quantification in the survey of trial 2 in 2014

\begin{tabular}{|c|c|c|c|c|c|c|}
\hline Specimen & Method & $\begin{array}{c}\text { No. of } \\
\text { participants }\end{array}$ & $\begin{array}{c}\text { Minimum } \\
(\mathrm{IU} / \mathrm{mL})\end{array}$ & $\begin{array}{c}\text { Maximum } \\
(\mathrm{IU} / \mathrm{mL})\end{array}$ & $\begin{array}{c}\text { Mean } \\
(\mathrm{IU} / \mathrm{mL})\end{array}$ & $\begin{array}{c}\mathrm{SD} \\
(\mathrm{IU} / \mathrm{mL})\end{array}$ \\
\hline MD $1402-\mathrm{N}$ & Not detected & 61 & & & & \\
\hline \multirow[t]{5}{*}{ MD 1402-O } & Roche AMPLICOR HCV monitor test & 1 & 148,000 & 148,000 & & \\
\hline & Roche COBAS TaqMan & 46 & 77,400 & 739,961 & 167,589 & 108,068 \\
\hline & Abbott HCV real-time PCR kit & 12 & 59,206 & 164,196 & 119,657 & 33,347 \\
\hline & Biosewoom HCV real-time PCR kit & 1 & 34,800 & 34,800 & & \\
\hline & Artus (Qiagen) HCV real-time PCR kit & 1 & 232,451 & 232,451 & & \\
\hline \multirow[t]{5}{*}{ MD 1402-P } & Roche AMPLICOR HCV monitor test & 1 & 7,580 & 7,580 & & \\
\hline & Roche COBAS TaqMan & 46 & 100 & 9,660 & 5,663 & 1,907 \\
\hline & Abbott HCV real-time PCR kit & 12 & 1,935 & 5,082 & 3,413 & 1,062 \\
\hline & Biosewoom HCV real-time PCR kit & 1 & 6,430 & 6,430 & & \\
\hline & Artus (Qiagen) HCV real-time PCR kit & 1 & 808 & 808 & & \\
\hline
\end{tabular}

Abbreviation: HCV, hepatitis $\mathrm{C}$ virus.

\section{고찰}

\section{1. 세포유전검사}

$14 \mathrm{CY}-01$ 은 발달장애소견을 보인 1세 환아의 말초혈액에 서 관찰된 염색체 이상으로 염색체 장완 $22 q 13.2$ 부위를 절단 점으로 하는 22 번 염색체 장완의 결실문항이었다. 참여한 44 개 기관 중 4 기관(9.1\%)은 말단부 결실(terminal deletion) 을 간질성 결실(interstitial deletion)로 표기하였으나 육안으 로 명확히 구분하기 어려울 수 있어 acceptable로 평가하였다. 22q13 결실증후군인 Phelan-McDermid syndrome은 신생아 기부터 발생하는 저긴장증, 운동 및 언어 발달지연, 자폐증 등 의 뚜렷한 신경 행동학적 결함을 특징으로 하며, 경한 안면기 형을 동반하는 것으로 알려져 있다. 불균형전위나 윤상 염색체
등의 구조재배열에 의한 이상은 발견이 용이하나 대부분을 차 지하는 결실의 경우 미세결실이 많아서 염색체 검사만으로 진 단이 안될 수 있다. DiGeorge 증후군/Velocardiofacial 증후군 등 $22 \mathrm{q} 11.2$ 의 미세결실에 의해 발생하는 질환과 감별이 필요 하며 FISH검사가 유용한 것으로 알려져 있다.

$14 \mathrm{CY}-02$ 는 저신장으로 내원한 7개월 된 환아의 말초혈 액에서 관찰된 염색체 이상소견으로 핵형의 target value 는 46,X, $\operatorname{del}(\mathrm{X})(\mathrm{p} 22.1)$ 또는 46,X, $\operatorname{del}(\mathrm{X})(\mathrm{p} 22.2)$ 인 증례였 다. 전체 44 개 기관 중 1 기관(2.3\%)에서 단완을 장완으로 잘 못 표기하였고 2 기관(4.5\%)에서는 $\mathrm{t}(\mathrm{X} ; 22)(\mathrm{p} 22.1 ; \mathrm{p} 11.2)$ 로 잘못 판독했으며 2기관(4.5\%)은 46,XX, del(X)(p22.1) 로 표기하여 unacceptable로 평가하였다. 정상 변이 염색체 (heteropolymorphism)는 추가로 기술할 필요는 없으나 이를 


\title{
Journal of LABORATORY MEDICINE and QUALITY ASSURANCE
}

\author{
Chang-Hun Park et al • 2014 Report on the External Quality Assessment
}

기술한 1 기관 $(2.3 \%)$ 은 acceptable로 평가하였다. 터너증후군 은 일반적으로 $45, \mathrm{X}$ 핵형이 절반 정도를 차지하고 나머지는 45,X/46,XX 또는 45,X/47,XXX 등의 섞임증과 46,X,del(Xq), 46,X,del(Xp), 46,X,i(Xq) 등의 구조이상 및 섞임증이 함께 존 재하는 형태를 보이는 것으로 알려져 있다.

14CY-03은 백혈구 증가증으로 의뢰된 69세 환자의 골 수 검체에서 발견된 염색체 이상으로 핵형의 target value는 46,XY, del(5) (q15q31),t(9;22) (q34;q11.2)[n]인 증례였다. 전체 44 개 기관 중 22 번 염색체 장완 표기(q)를 하지 않은 1 기관(2.3\%)에서 unacceptable로 평가하였고 1 기관(2.3\%) 은 22번 염색체 이상을 발견하지 못하고 $\operatorname{der}(9)$ 으로 표기하 여 unacceptable로 평가하였다. Philadelphia (Ph) 염색체인 $\mathrm{t}(9 ; 22)$ 는 $\mathrm{BCR} / \mathrm{ABL1}$ 재배열을 만들어 만성골수성 백혈병 등을 일으키며 만성골수성 백혈병에서 accelerative phase나 blastic phase의 $80 \%$ 에서는 $\mathrm{Ph}$ 염색체 이외 추가적인 염색체 이상이 동반되고 extra Ph chromosome, $+8,+19, \mathrm{i}(17 \mathrm{q})$ 등 이 빈도가 높은 것으로 잘 알려져 있다.

$14 \mathrm{CY}-04$ 는 상복부 통증과 체중 감소를 보인 50세 환자 의 골수 검체에서 관찰된 염색체 이상으로 $47, \mathrm{XY}, \mathrm{t}(6 ; 14)$ (p21.1;q32), +12[n] 증례였다. 전체 44개 기관 중 염색체 이 상을 권장되는 band resolution보다 낮은 300-band로 표기 한 1 기관 $(2.3 \%)$ 에 대해서는 acceptable로 평가하였다. 본 증례의 염색체 이상인 $\mathrm{t}(6 ; 14)(\mathrm{p} 21.1 ; \mathrm{q} 32.3)$ 는 주로 다발성 골수종(multiple myeloma)의 3-4\%에서 관찰되고 diffuse large B cell lymphoma (DLBCL), chronic lymphocytic leukemia/small lymphocytic lymphoma 등의 mature B-cell lymphoma에서도 일부 관찰되며 IGH/CCND3의 유전자 재 배열을 일으키는 것으로 알려져 있다.

$14 \mathrm{CY}-05$ 는 양수검사상 염색체 이상을 보인 부모의 말초 혈액에서 관찰된 염색체 이상소견으로 핵형의 target value 는 46,XY,inv(1)(q25.3q42.1)인 증례였다. 전체 44개 기관 중 권장되는 band resolution보다 낮은 400-band resolution 으로 표기한 1 기관(2.3\%)에 대해서 acceptable로 평가하였 다. 본 증례에서 관찰된 염색체이상인 완내역위(paracentric inversion)의 정확한 빈도는 알려져 있지 않으나 대략 0.090.48 명/ 1,000 명의 빈도를 보이고, 특별히 임상적 의의는 없는 것으로 알려져 있다. 일부 반복 유산이나 비정상 아이를 가질 확률은 낮지만 증가할 수 있다고 알려져 있다.

$14 \mathrm{CY}-06$ 은 신경관 이상이 의심되는 임신 23주 태아의 양수 에서 관찰된 염색체 이상으로 46,XX,t(2;19)(q33;p13.1)증례 였다. 전체 43개 기관 중 올바른 성염색체를 표기하지 않은 1 기관 $(2.3 \%)$ 과 $\mathrm{t}(2 ; 9)$ 로 잘못 표기한 1 기관(2.3\%)에 대해서 unacceptable로 평가하였다. 본 증례의 염색체 이상은 특별히 임상적 의의가 없는 것으로 알려져 있다. 하지만 일부 반복 유 산이나 비정상 아이를 가질 확률은 낮지만 증가할 수 있다고도 알려져 있다.

$14 \mathrm{CY}-07$ 은 심초음파검사상 심실중격결손증을 보인 생 후 1 개월 환아의 말초혈액에서 관찰된 염색체 이상으로 47 , $\mathrm{XY}, \mathrm{t}(3 ; 21)(\mathrm{p} 13-21.3 ; \mathrm{q} 22.1),+21$ 증례였다. 전체 43개 기관 중 2개 기관(4.7\%)은 'two band rule'을 벗어난 break point 를 기술하여 unacceptable로 평가하였다. 그리고 21번 염색체 의 추가를 표기하지 않은 1 기관(2.3\%)과 염색체 재배열을 결 실로 판독하여 47,XY, $\operatorname{del}(3)(\mathrm{p} 21.1),+\operatorname{del}(3)$ (q10)으로 잘못 표기한 1 기관(2.3\%)과 염색체 수를 46으로 잘못 표기한 1 기 관(2.3\%)에 대하여 unacceptable로 평가하였다. 다운증후군 은 일반적으로 신생아 $1 / 700$ 명의 빈도를 보이고, 염색체 전좌 를 함께 동반한 경우는 더 드물게 발생하는데 부모에게서 $21 \mathrm{q}$ 와 관련된 염색체 전좌를 가질 경우 다운증후군의 위험도를 증 가시킨다고 알려져 있다.

$14 \mathrm{CY}-08$ 은 안면기형을 보이는 7세 환아의 말초혈액에서 관 찰된 염색체 이상으로 46,XY, del(3)(q23q25.3) 증례였다. 전 체 43 개 기관 중 1 기관(2.3\%)은 권장되는 band resolution보 다 낮은 400-band로 표기하였지만 acceptable로 평가하였다. 본 증례의 염색체 이상인 $3 \mathrm{q}$ 미세결실증후군은 결실된 범위에 따라 다양한 임상증상이 보고되고 있는데 주로 소두증과 눈과 귀의 이형성을 동반한 안면기형과 발달장애를 보이는 드문 질 환으로 알려져 있다.

14CY-09는 말초혈액 내 모세포(blasts)가 관찰되는 52세 환자의 골수에서 관찰된 염색체 이상으로 $46, \mathrm{XY}, \mathrm{t}(8 ; 9 ; 21)$ (q22;q32;q22), del(9) (q22q32)[n] 증례였다. 전체 43개 기 관 중 13 기관(30.2\%)은 21번 염색체 이상을 발견하지 못하고 $\mathrm{t}(8 ; 9)$ 만 표기하여 unacceptable로 평가하였다. 1기관(2.3\%) 은 $\mathrm{t}(8 ; 9 ; 21)$ 의 three-break 재배열을 $\mathrm{t}(8 ; 9)$ 와 $\mathrm{t}(9 ; 21)$ 의 각 각의 two-break 재배열로 해석하였고 clone 수도 기술하지 않아서 unacceptable로 평가하였다. 염색체 재배열에 9q 또 는 $21 \mathrm{q}$ 가 참여한 것을 발견하지 못한 각각 1 기관씩 총 2 기관 (4.7\%)에 대하여 unacceptable로 평가하였다. 본 증례의 염 색체 이상인 $\mathrm{t}(8 ; 9 ; 21)$ 과 같은 variant $\mathrm{t}(8 ; 21)$ 은 $3 \%$ 에서 관 찰되는 것으로 알려져 있다. $\mathrm{T}(8 ; 21)$ 은 대부분 $\mathrm{AML}-\mathrm{M} 2$ 에 속하고 드물게 $\mathrm{M} 1$ 또는 $\mathrm{M} 4$ 로 진단되기도 하며, 전체 $\mathrm{AML}$ 의 $10 \%, \mathrm{M} 2$ 의 $40 \%$ 를 차지한다. 소아 $\mathrm{AML}$ 에서 가장 흔한 염색체 이상이고, 평균 연령은 30세 정도이며 노인에서는 드 물다고 알려져 있다. $75 \%$ 에서 추가적 염색체 이상이 동반되 는데, 주로 성염색체 소실이 있고 그 외 $\operatorname{del}(9 q),+8,-7$ 등이 


\section{Journal of LABORATORY MEDICINE and QUALITY ASSURANCE}

Chang-Hun Park et al • 2014 Report on the External Quality Assessment

있다. T(8;21)은 특징적인 형태학적 소견과 CD19 (early B) 와 CD56 (natural killer)항원을 표현하는 면역표현형 특징을 나타내며, 분자생물학적으로는 RUNX1/RUNX1T1(AML1) $E T O)$ 유전자 재배열을 가진다. $90 \%$ 이상 완전관해가 되지만 재발이 높은 편이며, 어른의 경우 비교적 긴 median survival 을 나타낸다.

$14 \mathrm{CY}-10$ 은 경부림프절 종대와 혈소판 감소증을 보인 34세 환자의 골수 검체에서 관찰된 염색체 이상으로 핵형의 target value는 51,XY,+3,+7,t(8;14) (q24.1; q32), +10,del(11) (q14q23), +18,+18[n] 또는 51,XY, +3, +7,t(8;14) (q24.1; q32), +10, del(11)(q23), +18,+18[n] 증례였다. 전체 43개 기관 중 2 기관(4.7\%)은 권장되는 band resolution보다 낮은 300-band로 표기하였지만 acceptable로 평가하였다. 1기관 $(2.3 \%)$ 은 $\mathrm{t}(8 ; 14)$ 를 발견하지 못하여서 unacceptable로 평가 하였다. 1 기관 $(2.3 \%)$ 은 $\mathrm{t}(8 ; 14)$ 를 $\mathrm{t}(8 ; 11 ; 14)$ 로 잘못 해석하 였고 clone 개수를 표기하지 않아서 unacceptable로 평가하 였다. 본 증례는 DLBCL로 진단된 골수검체였다. 확인된 염 색체이상인 $14 \mathrm{q} 32$ 의 염색체 재배열은 모든 DLBCL의 절반 에서 관찰될 수 있으며 3 번, 7 번 그리고 18 번 염색체의 추가 는 DLBCL에서 주로 관찰될 수 있다. T(8;14) (q24;q32) 또 는 variant t(8q24)는 Burkitt lymphoma에서 발견되지만 $\mathrm{DLBCL}$ 의 $10 \%$ 에서도 관찰될 수 있다. 덧붙여 X와 12 번 염색 체의 추가 또는 Y, 6 번, 13 번, 15 번 그리고 17 번 염색체의 소 실도 DLBCL에서 주로 관찰될 수 있다.

염색체검사에서 band resolution을 혼용 표기한 경우에 대 해서는 하반기부터 unacceptable로 평가하는 것으로 안내하 였고 상반기인 $14 \mathrm{CY}-03$ 과 $14 \mathrm{CY}-05$ 문항에서 400-band와 550-band resolution을 혼용 표기한 각각 1기관 $(2.3 \%)$ 씩 2 기관에 대해서는 acceptable로 평가하였다. 하반기에 band resolution을 혼용 표기한 기관은 없었다.

2014년 5월에 실시된 첫 번째 FISH검사항목은 총 5예 로 각각 Trisomy 21이 있는 검체, Prader-Willi/Angelman syndrome과 관련된 검체, $B C R / A B L 1$ 재배열이 있는 검체, $\mathrm{CDKN} 2 \mathrm{~A}$ 이상이 있는 검체, D7S522 이상이 있는 검체들이 었으며, $C D K N 2 A$ 의 homozygous deletion을 "within normal limits for CDKN2A' 또는 'abnormal with heterozygous deletion of $C D K N 2 A^{\prime}$ 로 판독한 기관이 각각 2기관씩 총 4 기관을 제외한 모든 참여기관에서 항목별 해당하는 이상소견 을 올바르게 판독하였다. 2014년 9월에 실시된 두 번째 FISH 검사항목은 총 5예로 각 항목별로는 Trisomy 21이 있는 검 체, 성염색체와 관련된 검체, PML/RARa 재배열이 있는 검 체, D13S319 이상이 있는 검체, TP53 이상이 있는 검체들이
었으며 Mosaic XXX를 'non mosaic XXX'로 판독한 1개 기관 을 제외하고 모든 참여기관에서 항목별 해당하는 이상소견을 올바르게 판독하였다. 하지만 각 기관별로 nomenclature 표 기는 예년과 비슷하게 다양한 것으로 확인되었다. ISCN 2013 기준에 따르면 정상과 비정상 세포가 같이 존재하는 경우 비 정상 세포의 수를 전체 세포 수와 함께 표기하도록 하며 정상 세포의 수는 쓰지 않도록 하고 있으나 정상 세포의 수를 병기 하는 오류 등이 일부 기관에서 관찰되었다. 그리고 다른 염색 체 probe를 동시 검사했을 경우 염색체 번호를 순서대로 표기 하지 않거나 같은 염색체에서 여러 probe를 사용할 경우 단 완 말단부( $\mathrm{p}$ terminal)에서 장완 말단부(q terminal)순서로 표기하지 않은 기관도 일부 관찰되었다. Metaphase FISH와 interphase FISH를 동시에 시행하는 경우 마침표(.)로 구분 하여 한 줄에 표기하는 것이 원칙이나 사선(/)을 사용하거나 metaphase 또는 interphase 결과만을 보고하는 기관이 일부 있었다. 그 밖에도 해당 loci에 대한 copy 수를 누락하는 등의 다양한 nomenclature 오류가 확인되어 향후 지속적인 교육 및 정도관리가 필요함을 확인할 수 있었다.

\section{2. 분자유전검사}

2014년도 분자미생물검사, 분자유전검사 정도관리는 전체 적으로 매우 우수한 결과를 보였다. 1 차 $B C R-A B L 1$ 검사항 목의 경우 1 개 기관이 양성 검체를 음성으로 보고하여 부적합 판정을 받았고, 이는 해당 기관이 $B C R-A B L 1$ major 유형만 검사하는 것과 관련될 것으로 추정되었다. $B C R-A B L 1$ 검사 가 시행되는 임상적 상황은 미리 재배열 유형을 구분하는 것이 불가능한 경우가 대부분이므로 major 재배열뿐 아니라 minor 재배열도 동시에 검출하는 검사환경이 임상적으로는 더 적절 할 것으로 판단된다. 1 차 $P M L-R A R A$ 검사항목의 경우 양성 검체를 준비하였으나 19 개 기관이 양성, 10 개의 기관이 음성 으로 보고함으로써, 일치율이 낮아 평가에서 제외되었다. 이처 럼 일치율이 낮은 이유는 검사법의 문제 외에도 검체의 제조 및 운송과정의 문제를 배제할 수 없을 것으로 추정된다.

FLT3-TKD항목에서 특정 검사키트를 사용한 기관들이 p.Asp835Val 돌연변이를 검출하지 못하였다. 이는 상기 돌연 변이가 해당 키트의 분석범위에 포함되지 않았을 가능성이 높 다. 하지만 상기 돌연변이는 FLT3-TKD 돌연변이 중 세 번째 로 흔한 것으로 알려져 있어 해당 키트를 사용하는 기관에서는 이러한 검사법의 제한에 대해 숙지할 필요가 있을 것으로 판단 되었다.

$\mathrm{DMD}$ 와 MTHFR검사에서 일부기관이 염기변이는 제대로 검출하였으나, 이의 임상적 의미 해석에서 예상결과와 불일치 


\section{Journal of LABORATORY MEDICINE and QUALITY ASSURANCE}

Chang-Hun Park et al • 2014 Report on the External Quality Assessment

한 결과를 보고하였다. 각 분자유전검사에서 돌연변이를 검출 하는 것뿐만 아니라 해당 염기변이의 해석에 있어 주의가 필요 할 것으로 판단된다.

Huntington disease에서 26 repeat allele이 평가 검체로 발송되었다. 삼염기 반복질환에서 검사기관들이 동일한 $\mathrm{PCR}$ and fluorescent based capillary electrophoresis법으로 검사 를 시행하여도 검사기관마다 반복수의 차이가 있는 것으로 알 려져 있다(Margolis). 삼염기 반복질환에서는 정상 및 비정상 의 반복수가 비교적 넓은 범위를 가지므로 대개의 경우 이러한 반복수의 차이가 임상적 해석의 불일치를 일으키는 경우는 드 물다. 하지만 이 증례에서처럼 임상적 해석의 경계에 해당하는 반복수의 경우는 문제가 될 수 있다. 따라서 삼염기 반복검사 의 경우 음성 및 양성의 정성적 평가와 더불어 반복수의 정확 도에 대한 평가가 향후 필요할 것으로 판단되며 아울러 반복수 검사의 표준화에 대한 노력이 필요할 것으로 보인다.

SMA에서 heterozygous deletion 증례가 발송되었고, MLPA 법을 사용하는 기관에서는 모두 heterozygous deletion으로 보고하였으나 RFLP법을 사용하는 기관에서는 이를 정상으로 보고하였다. 이는 RFLP법의 검사법 한계로 보이며 해당 검사 법을 사용하는 기관에서는 이러한 검사법 한계를 숙지할 필요 가 있다.

$\mathrm{DNA}$ 염기서열분석항목에서 $\mathrm{SCN} 5 \mathrm{~A}$ 의 c. $3578 \mathrm{G}>\mathrm{A}$, p.Arg1193Gln, heterozygote 증례가 발송되었는데, 해당 변 이는 문헌에 따라 임상적 의미가 서로 상이한 것으로 보고되 어 있다. Maekawa 등[6]은 해당 변이를 정상인에서의 빈 도가 $1 \%$ 이상인 양성 변이로 보고하였고, Vatta 등[7]은 기 능 연구를 통해 질병연관 돌연변이로 보고한 바 있다. 이처럼 임상적 의미가 상충되는 경우 해당 변이는 임상적 의미가 불 확정인 염기변이(unclassified variant of unknown clinical significance)로 보고하는 것이 바람직할 것으로 보인다. 또한 일부 기관에서 $M E N 1, M E C P 2$ 에서 오답을 보고하였는데 유 전자변이 명명과 보고의 경우 $\mathrm{HGVS}$ 및 $\mathrm{ACMG}$ 관련 지침을 준수하는 것을 권장한다[8,9].

$\mathrm{HBV}, \mathrm{HCV}$ 정량검사의 경우 peer group의 기관 숫자가 충 분치 않아 정규 평가에서 제외되고 있다. 하지만 동일한 검사 $\mathrm{kit}$ 를 사용하더라도 종종 기관마다 최대 1,000 배까지 차이를 보이고 있어 각 peer group의 평균과 표준편차를 적극 외부정 도관리에 이용하도록 권장된다.

\section{진단유전학분과위원회 위원(2014)}

김선희(위원장, 성균관대학교 의과대학), 김은지(간사, 삼
성서울병원), 김종원(성균관대학교 의과대학), 조현찬(한림대 학교 의과대학), 박성섭(서울대학교 의과대학), 이우인(경희 대학교 의과대학), 서을주(울산대학교 의과대학), 이유경(순 천향대학교 의과대학), 김재석(한림대학교 의과대학), 기승정 (전남대학교 의과대학), 기창석(성균관대학교 의과대학), 공 선영(국립암센터), 김지명(충남대학교 의과대학), 한성희(서 울의과학연구소), 탁은영(삼성서울병원), 이지영(서울아산병 원), 조성임(서울대학교병원)

\section{REFERENCES}

1. Kim SH, Ki CS, Kim S, Kwon MJ, Kim JW, Park SS, et al. Annual report on external quality assessment in diagnostic genetics in Korea (2009). J Lab Med Qual Assur 2010;32:147-70.

2. Kim SH, Ki CS, Jeon BR, Lee ST, Yoo EH, Kim JW, et al. Annual report on external quality assessment in diagnostic genetics in Korea (2008). J Lab Med Qual Assur 2009;31:161-81.

3. Kim SH, Ki CS, Kim JH, Oh SH, Kim JW, Park SS, et al. Annual report on external quality assessment in diagnostic genetics in Korea (2007). J Lab Med Qual Assur 2008;30:167-87.

4. Kim SH, Kim JW, Ki CS, Kim IS, Nam MH, Cho HJ, et al. Annual report on external quality assessment in diagnostic genetics in Korea (2005). J Lab Med Qual Assur 2006;28:153-67.

5. Shaffer LG, McGowan-Jordan J, Schmid M; International Standing Committee on Human Cytogenetic Nomenclature. ISCN 2013: an international system for human cytogenetic nomenclature (2013). Basel: Karger, 2013.

6. Maekawa K, Saito Y, Ozawa S, Adachi-Akahane S, Kawamoto M, Komamura K, et al. Genetic polymorphisms and haplotypes of the human cardiac sodium channel alpha subunit gene (SCN5A) in Japanese and their association with arrhythmia. Ann Hum Genet 2005;69:413-28

7. Vatta M, Dumaine R, Varghese G, Richard TA, Shimizu W, Aihara N, et al. Genetic and biophysical basis of sudden unexplained nocturnal death syndrome (SUNDS), a disease allelic to Brugada syndrome. Hum Mol Genet 2002;11:337-45. 


\section{Journal of LABORATORY MEDICINE and QUALITY ASSURANCE}

Chang-Hun Park et al • 2014 Report on the External Quality Assessment

8. Richards CS, Bale S, Bellissimo DB, Das S, Grody WW, Hegde MR, et al. ACMG recommendations for standards for interpretation and reporting of sequence variations: revisions 2007. Genet Med 2008;10:294-300.
9. Zhang VW, Wang J. Determination of the clinical significance of an unclassified variant. Methods Mol Biol 2012;837:337-48.

진단유전학분과 신빙도조사 결과보고(2014) 박창훈 ${ }^{1}$ - 신상용 $・$ 박현웅 ${ }^{2}$ - 조성임 ${ }^{2}$ 성문우 ${ }^{2}$ 박성섭 ${ }^{2}$ - 김선희 $\left.\right|^{1}$ 대한임 상검사정도관리협회 진단유전학분과위원회

${ }^{1}$ 성균관대학교 의과대학 삼성서울병원 진단검사의학과, ${ }^{2}$ 서울대학교 의과대학 서울대학교병원 진단검사의학과

진단유전분과에서의 외부정도관리는 임상적 중요성과 검사항목이 점차 증가함에 따라 더욱 중요해지 고 있는 항목이다. 세포유전학 분야인 염색체검사 신빙도조사는 2014년 두 차례에 걸쳐 총 10증례에 대하여 실시되었으며, 분자유전검사 신빙도조사 역시 두 차례에 걸쳐 모두 31항목, 분자미생물검사 역 시 두 차례에 걸쳐 6 항목에 대하여 실시되었다. 염색체 분야는 44 개 기관이 참여하였으며, 형광제자리 부합법 분야는 33 개 기관이 참여하였고, 분자유전검사 분야는 1 차와 2 차에 각각 58 개, 56 개 기관이

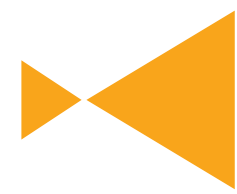

Journal of LABORATORY MEDICINE and

QUALITY ASSURANCE 참여하였고 분자미생물검사 분야는 130 개 기관이 참여하였다. 염색체 분야와 형광제자리부합법 분야 에서 모두 합격 판정을 받았다. 분자유전검사 분야는 백혈병/림프종 분자진단검사, JAK2, FMS-like tyrosine kinase 3 (FLT3)-ITD, FLT3-TKD, KRAS, EGFR, BRAF, KIT, BRCA1, BRCA2, TP53, ATP7B, FGFR3, Huntington disease, spinocerebellar ataxia, spinal and bulbar muscular atrophy, mitochondrial encephalopathy with lactic acidosis and stroke like episodes, myoclonic epilepsy ragged red fibre, Prader-Willi/Angelman syndrome, Duchenne muscular dystrophy, spinal muscular atrophy, fragile X syndrome, GJB2, KIT, TGFBI 분자진단검 사, $\mathrm{ABO}$, apolipoprotein $\mathrm{E}$ 및 methylenetetrahydrofolate reductase 유전자형 검사, DNA 염기서 열분석 평가, RET, LHON를 시행하였고, 분자미생물검사 분야는 human papilloma virus, 결핵균, hepatitis B virus (정성, 정량), hepatitis C virus(정성, 정량) 평가를 시행하였고 대부분의 기관에서 합격 판정을 받았다. 2014년 시행한 진단유전학분과 외부정도관리는 각 기관에 대한 지속적인 교육효 과와 더불어 검사의 양과 질적인 측면에 있어서 더욱 향상된 결과를 보였다.

(J Lab Med Qual Assur 2015;37:64-83)

교신저자: 김선희

우)135-710 서울시 강남구 일원로 81, 성균관대학교 의과대학 삼성서울병원 진단검사의학과

Tel: 02)3410-2704, Fax: 02)3410-2719, E-mail: sunnyhk@skku.edu 